\title{
Synthesis of Polyynes Using Dicobalt Masking Groups
}

\author{
Daniel R. Kohn, Przemyslaw Gawel, Yaoyao Xiong, Kirsten E. Christensen, and Harry L. Anderson*
}

University of Oxford, Department of Chemistry, Chemistry Research Laboratory, Oxford, OX1 3TA, United Kingdom

\begin{abstract}
Extended triisopropylsilyl end-capped polyynes have been prepared from the corresponding tetracobalt complexes by removing the complexed dicobalt tetracarbonyldiphenylphosphinomethane $\left(\mathrm{Co}_{2}(\mathrm{CO})_{4} \mathrm{dppm}\right)$ moieties. Unmasking of this 'masked alkyne equivalent' was

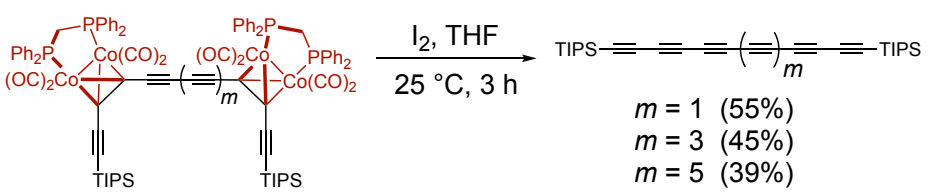
achieved under mild conditions with elemental iodine at room temperature, making it possible to obtain fragile polyynes with up to 20 contiguous sp-hybridized carbon atoms. The $\mathrm{Co}_{2}(\mathrm{CO})_{4} \mathrm{dppm}$ moiety has a strong geometric and steric effect on the polyyne, but does not have a marked electronic effect on the terminal alkyne, as indicated by NMR and IR spectroscopy, density functional theory calculations and X-ray crystallography. An unusual 'alkyne hopping' migration of the dicobalt group was noticed, as a minor side reaction during copper-catalyzed Eglinton coupling.
\end{abstract}

\section{Introduction}

Polyynes are fragile molecules, and they readily undergo cross-linking reactions, leading to decomposition and sometimes even to explosions. ${ }^{1}$ One method of circumventing this undesired reactivity is to conceal the alkyne as a 'masked alkyne equivalent' (MAE). ${ }^{2}$ The alkyne-dicobalt carbonyl moiety is a potential MAE, as it can reversibly complex a $\mathrm{C} \equiv \mathrm{C}$ bond (Figure 1a). ${ }^{3-5}$ The affinity of cobalt $(0)$ carbonyl complexes for alkynes is utilized in many important reactions such as the Nicholas reaction ${ }^{6}$ and the Pausson-Khand reaction. ${ }^{7,8}$ Cobalt clusters have also been used as electrochemical probes in acetylenic molecular wires. ${ }^{9-12}$

The demand for new organic semiconductors has led to increasing interest in carbon-rich materials ${ }^{13}$ and alkynes play an essential role in this field. ${ }^{13-19}$ The dicobalt carbonyl MAE group is particularly interesting for synthesizing acetylene-based structures because it can stabilize conjugated alkynes in two ways. Firstly, its steric bulk prevents close contacts between $s p$ chains, blocking cross-linking reactions. ${ }^{\text {la }}$ Secondly, it breaks the conjugation of the polyyne by changing the hybridization of the carbon atoms from $s p$ to $s p^{3}$. Additionally, it induces significant bending between the attached groups, aiding formation of curved structures. ${ }^{20,21}$ The pristine $\mathrm{Co}_{2}(\mathrm{CO})_{6}$ group can be removed by oxidation, ${ }^{22}$ alkyne-ligand exchange ${ }^{23}$ or flash vacuum pyrolysis. ${ }^{24}$ However, it is more useful when modified to incorporate a bis(diphosphinomethane) ligand, which improves the stability of the complexes but makes the MAE more difficult to unmask. ${ }^{25,26}$ Lewis et al. prepared tetracobalt complexes of tetraynes with the $\left(\mathrm{Co}_{2}(\mathrm{CO})_{4} \mathrm{dppm}\right)$ group and used ferric nitrate to unmask this moiety for the first time. ${ }^{27}$ The synthesis of two carbon-rich compounds with curved acetylenic $\pi$-systems has been attempted via their masked cobalt complexes. In the first example, Diederich and coworkers used a cobalt-masked triyne to assemble a hexacobalt masked cyclo[18]carbon macrocycle (Figure 1b). ${ }^{20}$ Haley et al. prepared an octacobalt complex of a cyclophane with a curved tetrayne bridges (Figure 1c).21 Both studies failed to unmask the desired curved $\pi$-systems from the corresponding cobalt complexes. Haley et al. successfully removed the dicobalt carbonyl moieties with excess $\mathrm{I}_{2}$ in simple model compounds, but this could not be reproduced on the octacobalt cyclophane complex. We believe the origin of these failures is the inherent reactivity of the desired curved polyynes, rather than the unmasking of the dicobalt group itself. a)

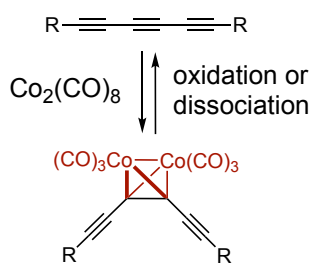

cobalt complexation

c)

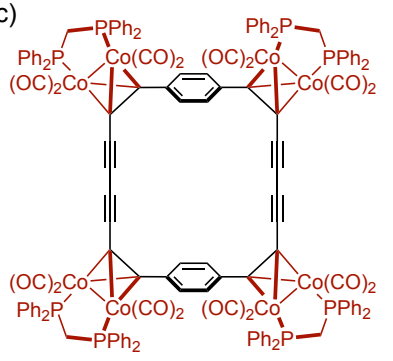

cyclophane octacobalt complex

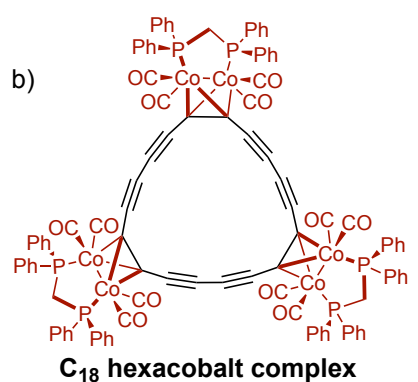

d)

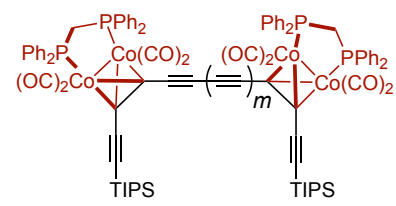

$m=1,3,5$

tetracobalt masked polyynes
Figure 1. a) Dicobalt complexation of an alkyne, b) $\mathrm{C}_{18}$ hexacobalt complex, ${ }^{20}$ c) $[8,8]$ paracyclophaneoctayne octacobalt complex, ${ }^{21} \mathrm{~d}$ ) tetracobalt masked polyynes (this work).

Polyyne synthesis via masked alkyne equivalent (MAE) groups, such as dibromoolefins, dialkynyl-3-cyclobutene-1,2diones and dialkynylmethylenebicyclo[4.3.1] deca-1,3,5-triene, offers high yields in relatively short systems.28-30 Further 
development of masking groups would be useful for the synthesis of longer polyynes. Several other MAEs have been developed and used in efforts to unmask cyclo $[n]$ carbons from the corresponding precursors. These MAEs require relatively harsh unmasking conditions, including high temperatures, ${ }^{31}$ flash vacuum pyrolysis, ${ }^{32} n$ - $\mathrm{BuLi}^{28,33}$ or intense UV light, ${ }^{34-36}$ which limits their application for long polyynes and other fragile alkynes.

The aim of this work was to prepare cobalt-masked acetylenic building blocks and cobalt-masked long polyynes (Figure 1d), as part of an effort towards carbon-rich supramolecular structures. ${ }^{37,38}$ Here we show that the dicobalt group is removed from tetracobalt complexes of long polyynes in moderate to good yields. The successful unmasking of polyynes from their corresponding tetracobalt complexes shows the great potential of this MAE. Further understanding of the effect of the dicobalt moiety on conjugated polyynes is obtained from analysis of NMR, IR, and UV-vis spectroscopy, density functional theory (DFT) and X-ray crystallography. We have also discovered a surprising rearrangement in the synthesis of the tetracobalt-masked polyynes during copper-catalyzed homocoupling.

\section{RESULTS AND DISCUSSION}

\section{Synthesis}

Three dicobalt-masked building blocks containing terminal oligoynes of different length were prepared in order to access a series of tetracobalt-masked polyynes. TIPS,TMS-protected triyne $\mathbf{1}$ was used because the TMS group can be selectively removed, while leaving the TIPS group untouched, using $\mathrm{K}_{2} \mathrm{CO}_{3}$ in $\mathrm{THF} / \mathrm{MeOH}$ at room temperature. ${ }^{39,40} \mathrm{We}$ anticipated that dicobalt complex formation with TIPS,TMStriyne $\mathbf{1}$ would occur at the central alkyne to give $\mathbf{2 a}$ (analogously to the reported bis-TIPS complex ${ }^{20}$ ) and that the regioisomer $\mathbf{2 b}$ would be a minor byproduct. However, we found that the major product is the undesired product $\mathbf{2} \mathbf{b}$, with the dicobalt group adjacent to the less bulky TMS group (45\% yield). The desired product $2 \mathbf{a}$ was isolated in $27 \%$ yield (Scheme 1). The identities were confirmed by NMR spectroscopy and X-ray crystallography, as discussed below. Despite the large amount of undesired regioisomer formed, this is a more efficient synthetic route than statistical deprotection of a bis-TIPS complex (Scheme S1, SI).

\section{Scheme 1. Cobalt complexation.}

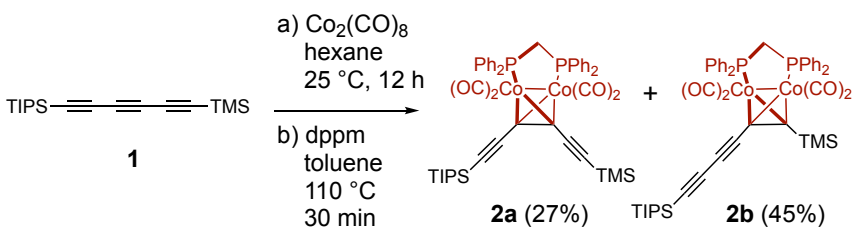

Deprotection of $\mathbf{2 a}$ with $\mathrm{K}_{2} \mathrm{CO}_{3}$ in $\mathrm{MeOH} / \mathrm{THF}$ yielded the desired cobalt complex 3 quantitatively (Scheme 2). The acetylenic chain in this cobalt complex can be readily extended via a Glaser coupling with TMS-acetylene. ${ }^{41}$ Use of an excess of TMS-acetylene, $\mathrm{CuCl}$ and TMEDA gave the desired butadiyne 4 in $82 \%$ yield (with bis-TMS-butadiyne as a side product, Scheme 2). A large excess of reagents is required to avoid homocoupling of $\mathbf{3}$. The structure of $\mathbf{4}$ was confirmed by single crystal X-ray diffraction, vide infra. Deprotection of $\mathbf{4}$ using $\mathrm{K}_{2} \mathrm{CO}_{3}$ in $\mathrm{THF} / \mathrm{MeOH}$ yielded the desired $\mathbf{5}$ in a quantitative yield. The acetylene chain extension methodology was used again to furnish $\mathbf{6}$ in $84 \%$ yield and the following deprotection gave terminal triyne $\mathbf{7}$ (Scheme 2). Complex $\mathbf{7}$ must be handled with care, as it is relatively unstable when dry; it decomposes over a period of a few hours at $20^{\circ} \mathrm{C}$ and a few weeks at -20 ${ }^{\circ} \mathrm{C}$. However, it is more stable than the corresponding unmasked terminal pentayne.

\section{Scheme 2. Cobalt oligoyne synthesis.}
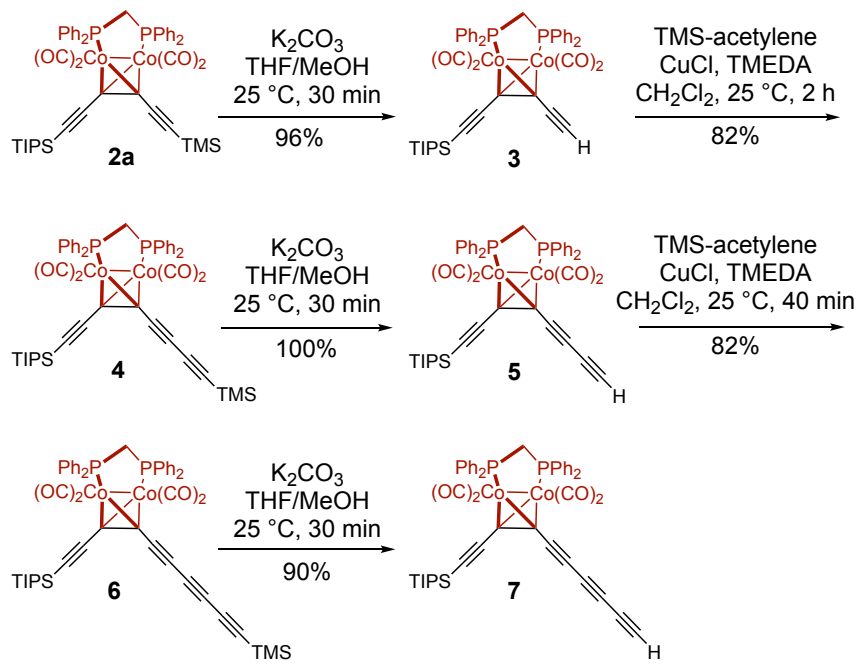

The oxidative homocoupling of $\mathbf{3}$ using Eglinton conditions, ${ }^{42} \mathrm{Cu}(\mathrm{OAc})_{2}$ in pyridine, gives two separable products. The expected isomer $\mathbf{8 a}$ is the major product, in $80 \%$ yield, but a regioisomer $\mathbf{8 b}$ can also be isolated in $7 \%$ yield (Scheme 3). The structures of these compounds were confirmed by analysis of single crystals, vide infra. Diederich and coworkers prepared a similar complex containing a butadiyne bridge, without reporting this type of isomerization. ${ }^{20,43}$ Repeating the reaction using different conditions, including Glaser-Hay ${ }^{44}$ coupling, shorter reaction times and heating (Scheme S3, S4) did not change the outcome, and, a small amount of rearranged product $\mathbf{8 b}$ was always formed. Surprisingly, formation of the partially rearranged hybrid of $\mathbf{8 a}$ and $\mathbf{8 b}$ was never detected. Despite investigation of this rearrangement we were unable to ascertain the reason for this unexpected behavior.

The analogous longer octatetrayne-linked dimer complex 9 was prepared via Eglinton coupling. Once again, two products were observed by TLC; however, the compound with the higher $R_{\mathrm{f}}$ decomposed during column chromatography on silica. By analogy to $\mathbf{8 b}$, we assume that the unexpected byproduct contains a hexayne. The stable product was identified as $\mathbf{9}$ by ${ }^{13} \mathrm{C}$ NMR spectroscopy, through observation of the characteristic signals from acetylene carbons adjacent to the TIPS group. The analogous complex $\mathbf{1 0}$ was also formed from 7 using Eglinton coupling conditions (Scheme 3). The loss of terminal acetylene peaks in the ${ }^{1} \mathrm{H}$ and ${ }^{13} \mathrm{C}$ NMR spectra, the increased symmetrization of the alkyl diphosphinomethane signal and the presence of the expected ${ }^{13} \mathrm{C}$ acetylene signals for the tetracobalt complex confirmed the successful formation of tetracobalt complex $\mathbf{1 0}$. 
Scheme 3. Synthesis of tetracobalt complexes 8a, 8b, 9, 10.
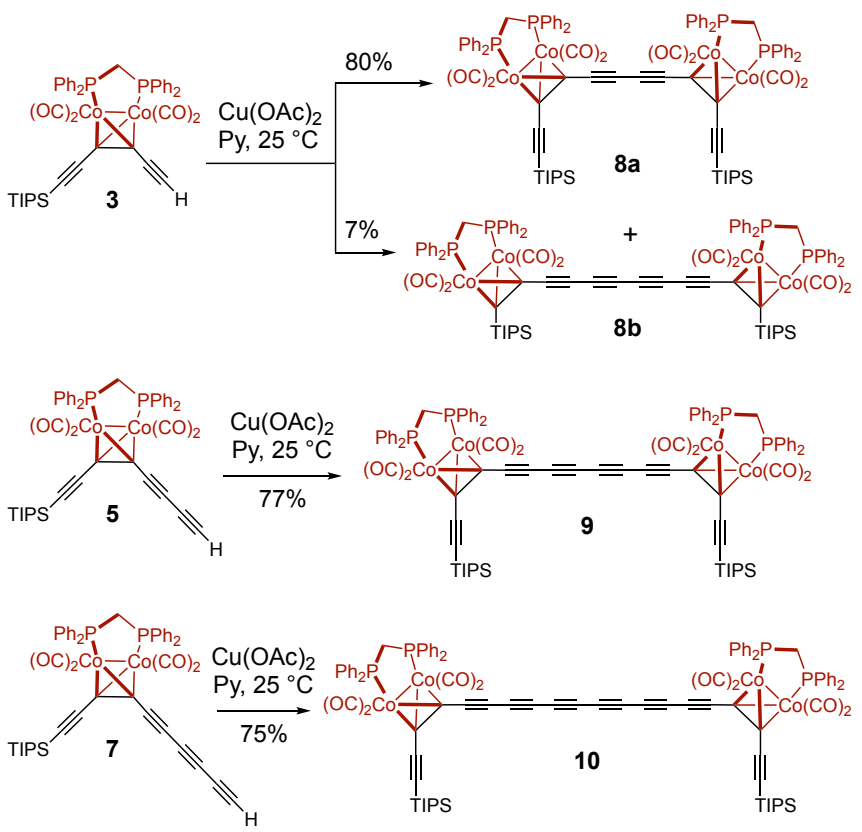

The removal of the $\mathrm{Co}_{2}(\mathrm{CO})_{4} \mathrm{dppm}$ masking group was first tested on simple cobalt complexes. Both $\mathbf{2 a}$ and $\mathbf{2} \mathbf{b}$ were used as model systems for optimizing the reaction conditions. We found that both $\mathbf{2 a}$ and $\mathbf{2 b}$ undergo decomplexation of the dicobalt group in good yield by oxidation with $\mathrm{I}_{2}$ in $\mathrm{THF}$, the conditions reported previously by Haley et al. (Scheme 4).21 The successful removal of the masking group in simple systems encouraged us to investigate extended polyynes.

Scheme 4. Removal of a dicobalt group; unmasking triyne 1 .

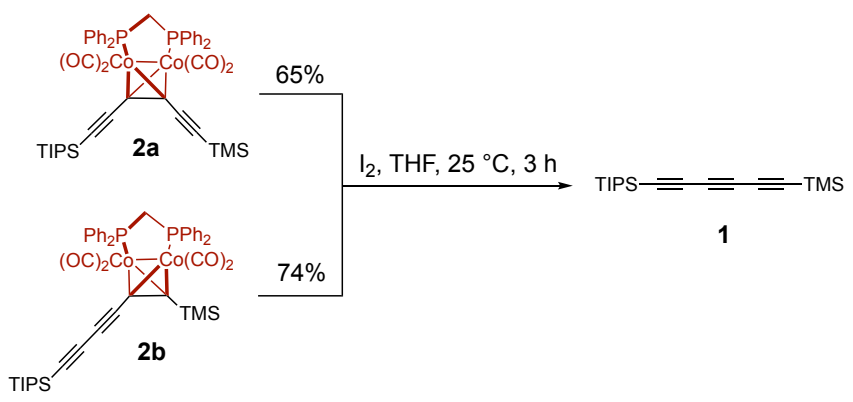

The tetracobalt complexes $\mathbf{8 a}, \mathbf{9}$ and $\mathbf{1 0}$ were unmasked using the conditions described above to give the corresponding polyynes in $39-55 \%$ yields (Scheme 5 ). The unmasked polyynes were purified easily by chromatography on silica gel with petroleum ether as the eluent to separate the desired non-polar TIPS polyyne from the polar cobalt species. As expected, the longest polyyne was isolated in a slightly lower yield, reflecting its lower stability. UV-vis spectroscopy was invaluable in identifying the desired polyynes, due to the characteristic vibronically coupled absorption bands (Figure S33).33 UV-vis spectroscopy is very sensitive to the presence of an incomplete reaction or other polyynic products, as both outcomes result in the presence of other chromophores with absorption bands that overlap with those of the desired polyynes. The products were conclusively identified by ${ }^{13} \mathrm{C}$ NMR spectroscopy. This is the first time, to the best of our knowledge, that the dicobalt masking moiety has been used in the synthesis of polyynes.
Scheme 5. Synthesis of polyynes 11-13.

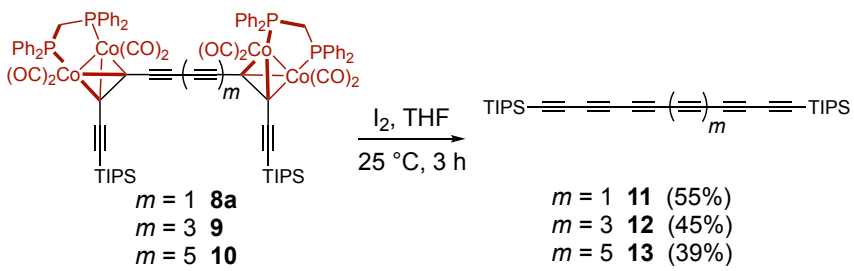

The yields for polyyne unmasking (Scheme 5) are significantly higher than those for the Fritsch-ButtenbergWiechell rearrangements reported by Tykwinski and coworkers for the synthesis of the same compounds. ${ }^{33}$ The octayne $\mathbf{7}$ is obtained in $45 \%$ yield from a tetracobalt complex. The same octayne was isolated in $10 \%$ yield from a dibromoolefin-masked precursor. ${ }^{33}$ It was not previously possible to directly unmask a decayne from a masked precursor; Tykwinski and coworkers reported that this reaction led only to decomposition. In contrast, decayne $\mathbf{1 3}$ is isolated in $39 \%$ yield after simple purification from tetracobalt complex 10. The lower yields of the longer polyynes reflect their lower stability, and may be attributed to decomposition under the reaction conditions. These results demonstrate that unmasking of the $\mathrm{Co}_{2}(\mathrm{CO})_{4} \mathrm{dppm}$ MAE is a promising methodology in polyyne synthesis and offers new opportunities in carbon-rich chemistry.

\section{NMR spectroscopy}

The ${ }^{1} \mathrm{H}$ NMR spectra of the regioisomers $\mathbf{2 a}$ and $\mathbf{2} \mathbf{b}$ are similar, as the variance between them is remote from any protons (Figure 2). The two geminal protons of the diphosphine bridge $\left(\delta_{\mathrm{H}} \approx 3.5 \mathrm{ppm}\right)$ are inequivalent, as observed in both spectra. There is a greater splitting of these signals in the $\mathbf{2 b}$ regioisomer, as the environments of the protons are more different. The chemical shift of the trimethylsilyl group supports this assignment, as the signal comes at an unusual chemical shift of $0.40 \mathrm{ppm}$ in $\mathbf{2 b}$. The TMS signal in $\mathbf{2} \mathbf{a}$ has a chemical shift of $0.25 \mathrm{ppm}$, which is in the usual range for a TMS group attached to an alkyne. The carbon atoms directly bonded to cobalt are observed as two triplets (due to coupling to ${ }^{31} \mathrm{P}$ ) at 75.0 and 91.5 ppm in $\mathbf{2 b}$, and as two broad signals at 68.9 and $71.5 \mathrm{ppm}$ in $\mathbf{2 a}$ (Figure 3). The chemical shifts are as expected for each isomer; two acetylenic carbons with satellites are observed in $\mathbf{2} \mathbf{a}$, in contrast to $\mathbf{2 b}$. The structures of $\mathbf{2} \mathbf{a}$ and $\mathbf{2} \mathbf{b}$ were confirmed by single crystal X-ray diffraction analysis, vide infra. 


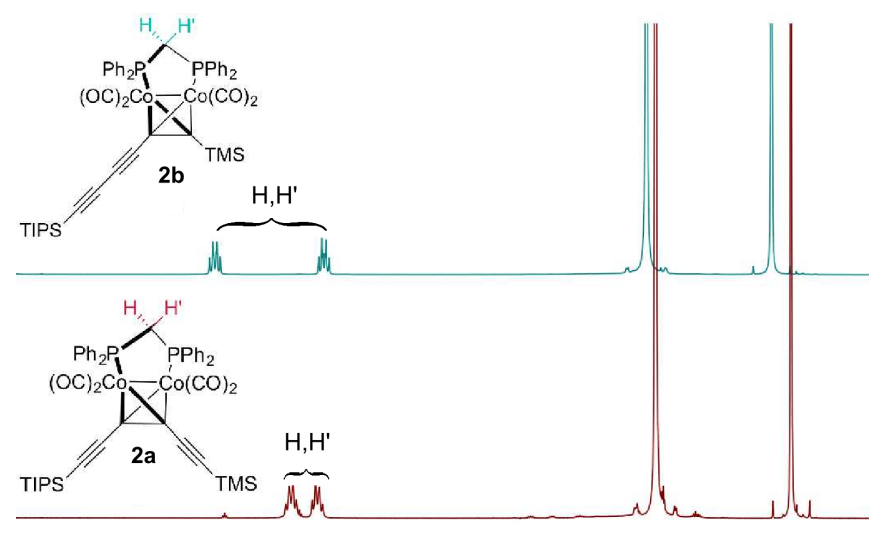

$\begin{array}{lllllllllll}5.0 & 4.5 & 4.0 & 3.5 & 3.0 & \delta / 1.5 & 2.0 & 1.5 & 1.0 & 0.5 & 0.0\end{array}$

Figure 2. Partial ${ }^{1} \mathrm{H}$ NMR spectra of isomers $\mathbf{2 a}$ and $\mathbf{2 b}(500$ $\mathrm{MHz}, \mathrm{CDCl}_{3}$ ).

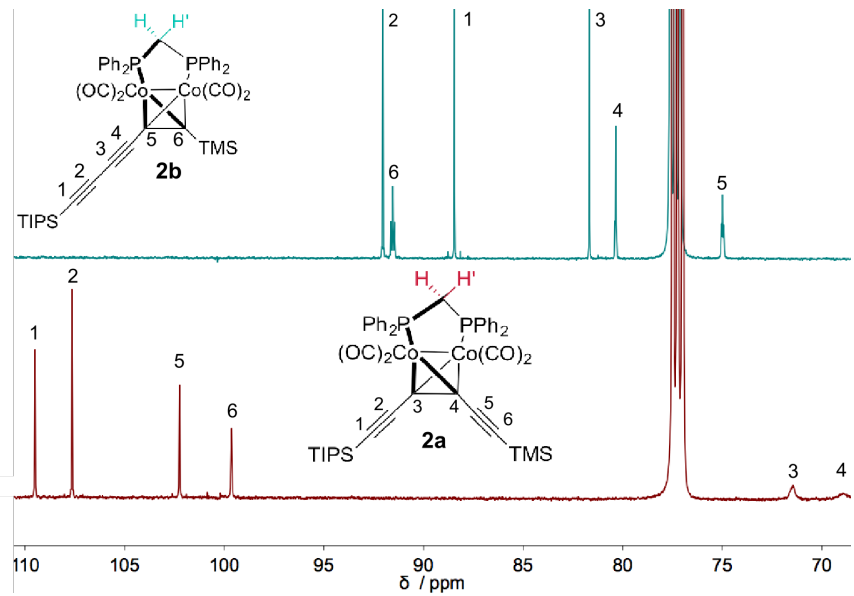

Figure 3. Partial ${ }^{13} \mathrm{G}$ NMR spectra of isomers $2 \mathbf{a}$ and $\mathbf{2 b}(125$ $\mathrm{MHz}, \mathrm{CDCl}_{3}$ ) with proposed assignments.

\section{Reactivity of terminal acetylene}

In the context of our research towards carbon rich supramolecular structures, we planned to form polyyne rotaxanes from cobalt complexes $\mathbf{3}, \mathbf{5}$ and 7, via active-metal template synthesis. ${ }^{37,45-47}$ However, experiments in this direction have not yet been successful. Hence, we sought to understand the differences in reactivity between dicobalt oligoynes $\mathbf{3}, \mathbf{5}, \mathbf{7}$ and their tris(3,5-di-t-butylphenyl)methyl (supertrityl, Tr*) endcapped oligoyne counterparts, which were previously used to prepare polyyne rotaxanes. $37,38,47$

The most striking property of the dicobalt acetylenes $\mathbf{3}, \mathbf{5}, \mathbf{7}$ is the unusually high chemical shift of the terminal acetylene protons (Table 1). In $\mathbf{3}$, this resonance appears at $3.63 \mathrm{ppm}$, which is $0.98 \mathrm{ppm}$ greater than that of the supertrityl monoyne counterpart. This difference diminishes as the distance from the end-capping group increases in the corresponding diyne and triyne. The same trend is reflected in the ${ }^{13} \mathrm{C}$ NMR spectra. The chemical shift of the terminal carbon in $\mathbf{3}$ is $11.8 \mathrm{ppm}$ larger than that for the analogous supertrityl compound. In the longest analogues, this difference is reduced to $8.5 \mathrm{ppm}(7 \mathrm{vs}$. Tr*

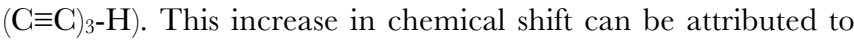
the electron-withdrawing effect of the dicobaltcarbonyl group or to deshielding by the phenyl substituents of the phosphine.

IR spectroscopy is a useful tool for providing insight into bond strengths in acetylenes. A decrease in the $\mathrm{C}-\mathrm{H}$ stretch frequency with increased number of acetylenes in the dicobalt oligoynes is observed (Table 1), which indicates a slightly weaker $\mathrm{C}-\mathrm{H}$ bond in $\mathbf{7}$ than in $\mathbf{3}$. The same overall trend is repeated in both series of compounds (with the exception of $\left.\operatorname{Tr}^{*}-(\mathrm{C} \equiv \mathrm{C})_{2}-\mathrm{H}\right)$.

Table 1. Comparison of $1 \mathrm{H}$ and ${ }^{13} \mathrm{C}$ chemical shifts and acetylenic C-H stretch frequencies in cobalt and supertrityl oligoynes. ${ }^{15}$
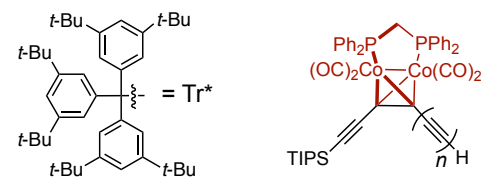

\begin{tabular}{cccc} 
Compound & $\begin{array}{c}\mathrm{C} \equiv \mathrm{C}-H \\
{ }^{1} \mathrm{H}_{\mathrm{H}} / \\
\mathrm{ppm}^{(\mathrm{a})}\end{array}$ & $\begin{array}{c}\mathrm{C} \equiv C-\mathrm{H}^{13} \mathrm{C} \\
\delta_{\mathrm{C}} / \mathrm{ppm}^{(\mathrm{a})}\end{array}$ & $\begin{array}{c}\mathrm{C} \equiv C-H \text { stretch } \\
\text { frequency } / \mathrm{cm}^{-1} \\
\text { (b) }\end{array}$ \\
\hline $\mathrm{Tr}^{*}-\mathrm{C} \equiv \mathrm{C}-\mathrm{H}$ & 2.65 & 72.0 & 3306.0 \\
$\mathrm{Tr}^{*}-(\mathrm{C} \equiv \mathrm{C})_{2}-\mathrm{H}$ & 2.10 & 66.7 & $3315.1^{(\mathrm{c})}$ \\
$\operatorname{Tr}^{*}-(\mathrm{C} \equiv \mathrm{C})_{3}-\mathrm{H}$ & 2.07 & 61.3 & 3282.2 \\
$\mathbf{3}$ & 3.63 & 83.8 & 3306.4 \\
$\mathbf{5}$ & 2.81 & 73.0 & 3305.8 \\
$\mathbf{7}$ & 2.43 & 69.8 & 3296.6
\end{tabular}

(a) ${ }^{1} \mathrm{H}$ and ${ }^{13} \mathrm{C}$ NMR spectra were recorded in $\mathrm{CDCl}_{3}$ at 400 and $100 \mathrm{MHz}$ respectively. (b) IR spectra recorded on thin films. (c) The stretch frequency for $\operatorname{Tr}^{*}-(\mathrm{C} \equiv \mathrm{C})_{2}-\mathrm{H}$ is from ref. 15 .

We also performed computational studies on both types of terminal oligoynes. The electrostatic potential maps (ESP) on total density surfaces show significantly higher charge accumulation over the oligoyne chain in dicobalt complexes compared to supertrityl end-capped oligoynes ( -0.04 vs. -0.02 a.u., respectively; Figures S37 and S38, SI). However, the positive charge on the terminal hydrogen is similar in both cases, suggesting similar reactivity. In order to get detailed charge distribution along the oligoyne chains, we calculated atomic charges using three different methods: Mulliken, Hirshfield, and Natural Population Analysis (Table S1, Table S2, SI). In all three methods, the positive charge on the terminal hydrogen atom increases with increasing acetylenic chain length (Figure S39, SI). In contrast, the charge difference between terminal carbon and hydrogen exhibits the reverse trend (Figure S40, SI). Nevertheless, the length-dependent changes, as well as the range of values, are very similar in both types of oligoynes suggesting similar reactivity.

In general, the multiple similarities between dicobalt and supertrityl oligoynes imply that incompatibility with the active metal template rotaxane formation is a result of incompatibility with oxidative coupling conditions, rather than reactivity differences of the terminal alkyne. The successful formation of tetracobalt complexes via homocoupling supports this conclusion (Scheme 3).

\section{Electronic absorption spectra and molecular orbitals}

UV-vis absorption spectra of all of the novel cobalt complexes were recorded $\left(\mathrm{CH}_{2} \mathrm{Cl}_{2}, 298 \mathrm{~K}\right)$. The change in absorption upon cobalt complexation of triyne $\mathbf{1}$ is pronounced (Figure 4). After complexation, the fine vibronic band (280-330 $\mathrm{nm}$ ) is dwarfed by a new broad absorption with a maximum at $290 \mathrm{~nm}$ and high molar absorption coefficient $\left(25000 \mathrm{M}^{-1} \mathrm{~cm}^{-1}\right)$. There is also a low-intensity broad feature at lower energy, which results from several weak transitions (Figures S42 and 
S43, SI). Solutions of $\mathbf{2} \mathbf{a}-\mathbf{7}$ in $\mathrm{CH}_{2} \mathrm{Cl}_{2}$ have an intense red color. The very broad signals of the other TMS-protected dicobalt complexes (4 and $\mathbf{6})$ did not reveal any particularly unexpected behavior (Figure S32, SI).

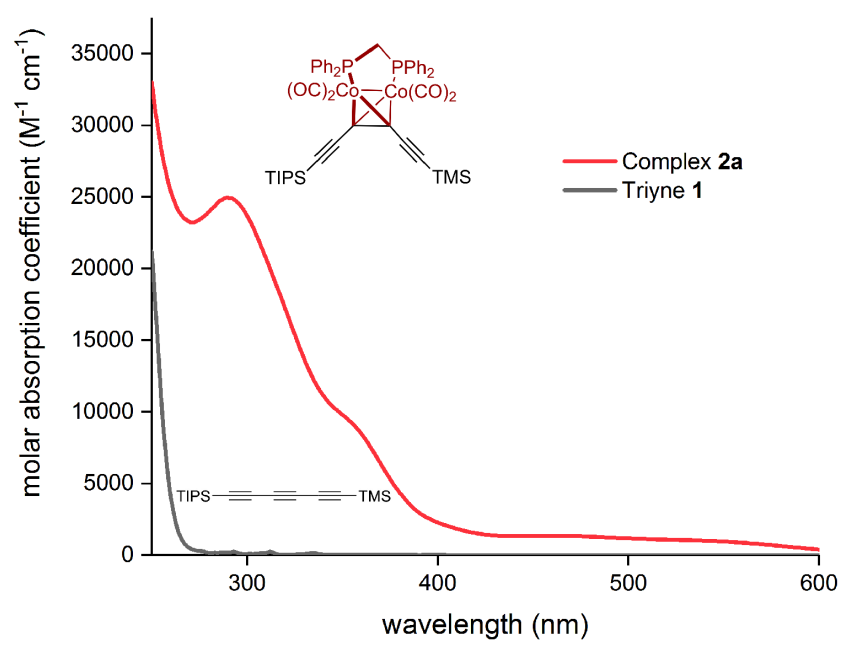

Figure 4. The effect of dicobalt complexation on electronic absorption spectra $\left(\mathrm{CH}_{2} \mathrm{Cl}_{2}\right)$.

The absorption spectra of tetracobalt polyyne complexes are significantly red-shifted compared to those of the dicobalt oligoynes (Figure 5), and there is a bathochromic shift with increasing length of polyyne. They are considerably more redshifted than those of the unmasked polyynes (Figure S33, SI).

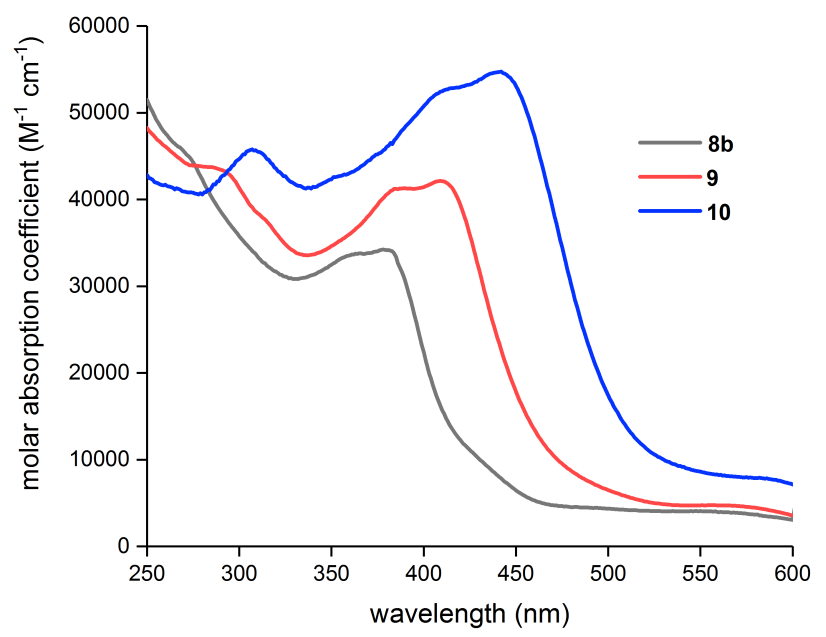

Figure 5. The effect of polyyne length on absorption in tetracobalt complexes 8a, 9, 10 (UV-vis spectra, $\mathrm{CH}_{2} \mathrm{Cl}_{2}$ ).

Frontier molecular orbitals were calculated for $\mathbf{8 a}, \mathbf{9}$ and $\mathbf{1 0}$ at the B3LYP/STO-3G level of theory (Figure 6), using the crystal structures of complexes $\mathbf{2 a}, \mathbf{4}$ and $\mathbf{6}$ as starting points for geometry optimization (Section S4, SI). In all cases, the HOMO is localized mainly on the polyyne core whereas the LUMO delocalizes into the cobalt atoms and carbonyl ligands. This implies a HOMO-LUMO transition that possesses significant charge transfer character, shifting electron density from the conjugated $\pi$-system to the metal carbonyl. The intense red color of all of the cobalt complexes could be attributed to a charge-transfer band, and this hypothesis is supported by the observation of modest solvatochromism for the cobalt complex $\mathbf{2 a} ; 48,49$ its absorption maximum shifts to the red by $358 \mathrm{~cm}^{-1}$ on changing the solvent from hexane to acetonitrile (Figures S34 and S35, SI).
HOMO

$8 a$

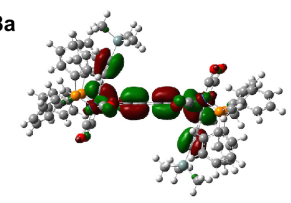

9

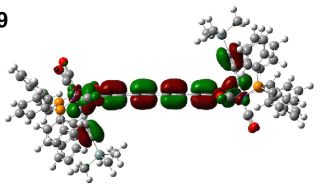

10

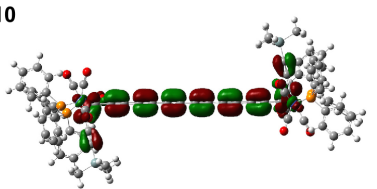

LUMO
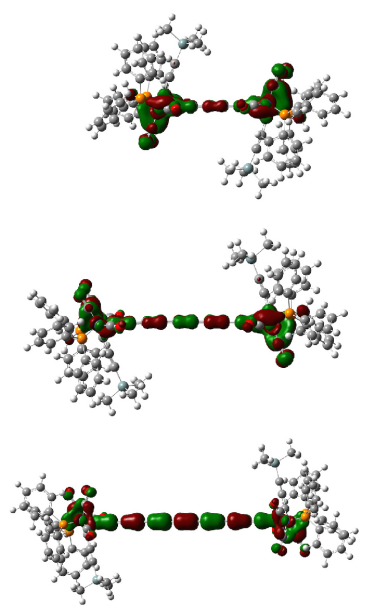

Figure 6. Calculated frontier molecular orbitals of $E$ isomers of 8a, 9 and $\mathbf{1 0}(\mathrm{DFT} / \mathrm{B} 3 \mathrm{LYP} / \mathrm{STO}-3 \mathrm{G})$.

\section{Crystallographic Analysis}

Single crystal X-ray diffraction studies provide insight into the geometries of cobalt-polyyne complexes, and acted as an essential tool for confirming the structure of these unusual compounds. The crystal structures of polyynes can reveal the bond length alternation (BLA) and the degree of deviation from linearity. ${ }^{50} \mathrm{BLA}$ is the difference between the carbon-carbon bond length of adjacent single and triple bonds. In polyynes, the BLA is defined as the difference in length between the central single and triple bonds. ${ }^{51,52}$

Here, seven crystal structures of cobalt-polyyne complexes are presented: $\mathbf{2 a}, \mathbf{4}, \mathbf{6}, \mathbf{2 b}, \mathbf{8 a}$ and $\mathbf{8 b}$ and bis-TIPS complex S6. All crystals were grown by layered addition of $\mathrm{MeOH}$ to a solution in $\mathrm{CHCl}_{3}$. Diffraction data for $\mathbf{8 a}$ and $\mathbf{8 b}$ were collected at $100 \mathrm{~K}$ using synchrotron radiation on beamline I19-1 at Diamond Light Source. The structures were solved using charge flipping ${ }^{53,54}$ with SuperFlip ${ }^{55}$ and refined using the full-matrix least-squares method within the CRYSTALS software package (Section S5). ${ }^{56,57}$ Crystallography proved to be an essential tool when distinguishing between the regioisomers $\mathbf{2 a}$ and $\mathbf{2 b}$ (Figure 7). The bond angles are broadly similar in the two regioisomers. However, the dppm ligand is directed towards TMS group in $\mathbf{2} \mathbf{a}$ and towards TIPS group in $\mathbf{2} \mathbf{b}$, which may be a result of crystal packing. The variation in the solid-state structures suggests that the conformation of the cobalt complex is dynamic in solution, as concluded from previous NMR spectroscopy studies. ${ }^{9,43}$ 


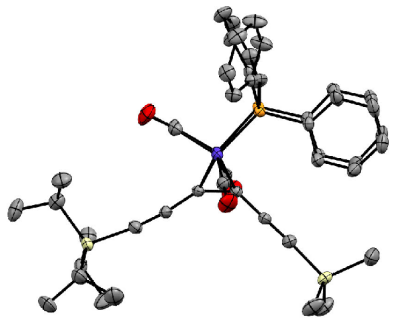

$2 a$

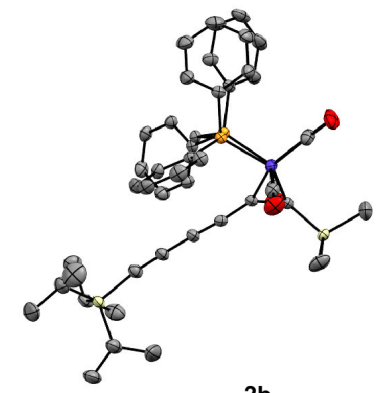

2b
Figure 7. Displacement ellipsoid plots of $\mathbf{2 a}$ and $\mathbf{2 b}(\mathrm{H}$ atoms and solvent omitted for clarity, thermal ellipsoids drawn at $50 \%$ probability).

Single crystal X-ray diffraction led to the serendipitous discovery of an unexpected product. As discussed above, when $\mathbf{3}$ was subjected to Eglinton coupling conditions, two products were observed $(\mathbf{8 a}$ and $\mathbf{8 b}$, Scheme 3 and Figure 8$)$. The end groups in $\mathbf{8 a}$ are oriented in $(E)$ fashion, with the TIPS groups perfectly anti-periplanar because the compound crystallizes with a center of symmetry. The diyne core is highly linear, while $\mathbf{8 b}$ has a far more curved polyyne chain and a slightly twisted synperiplanar geometry of the TIPS groups.

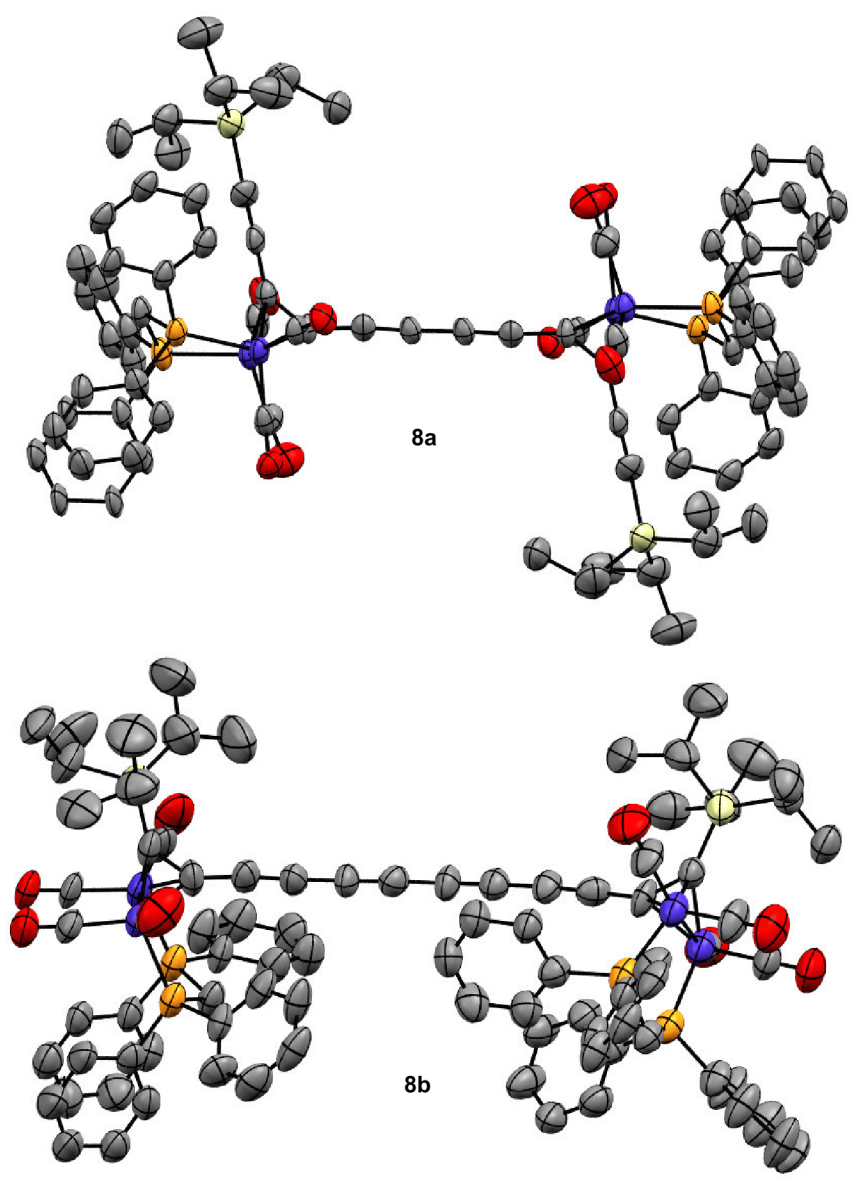

Figure 8. Displacement ellipsoid plots of regioisomers $\mathbf{8 a}$ and $\mathbf{8 b}$ ( $\mathrm{H}$ atoms and disorder omitted for clarity, thermal ellipsoids drawn at $50 \%$ probability)

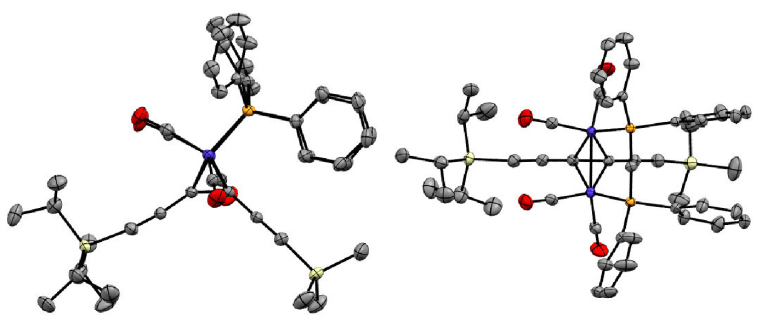

$2 a$
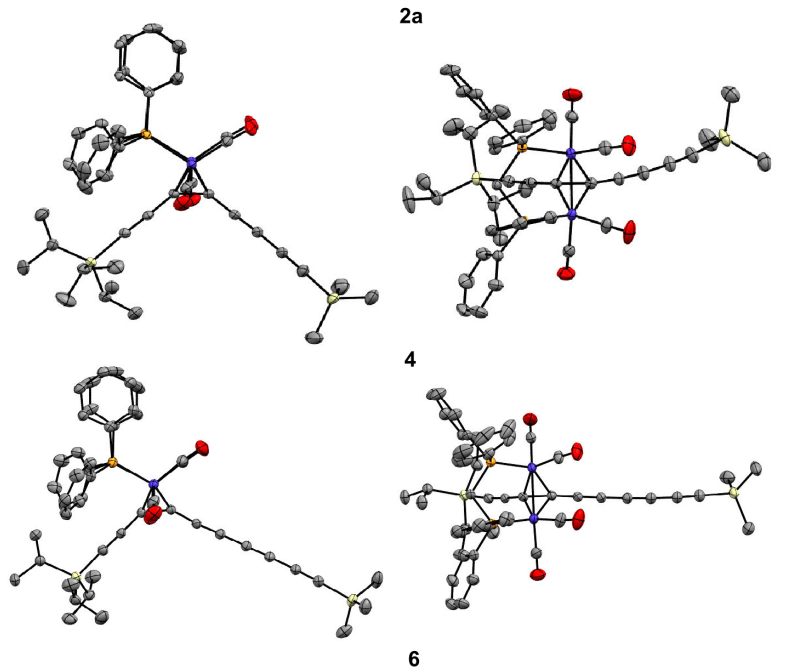

Figure 9. Displacement ellipsoid plots of $2 \mathbf{a}, \mathbf{4}$ and $\mathbf{6}(\mathrm{H}$ atoms omitted for clarity, thermal ellipsoids drawn at $50 \%$ probability)

Systematic analysis of the set of complexes with increasing length of $s p$-chain was performed based on the crystal structures of 2a, $\mathbf{4}$ and $\mathbf{6}$ (Figure 9, Table 2). The length of the $\mathrm{C}_{\mathrm{sp} 3}-\mathrm{C}_{\mathrm{sp}}$ bond decreases as the polyyne gets longer. In $\mathbf{2} \mathbf{a}$, this bond is markedly longer than in $\mathbf{6}(0.02 \AA)$. In contrast, there appears to be no relationship between the length of the Co- $\mathrm{C}$ bond and the polyyne length. The average Co-C bond length is $1.95 \AA$ in all of the compounds. This implies that the complexation of the dicobalt group is of very similar strength in all cases. The BLA is smaller in the longer masked polyyne $\mathbf{6}$ than in $\mathbf{4}$. One of the features that attracted us and others to the dicobalt alkyne masking group is the angle that it infers on the polyyne system while masking it. As the chain lengthens, the angle $\theta_{2}$ increases and $\theta_{1}$ decreases (Table 2). 
Table 2. Bond lengths and angles in crystal structures of compounds $\mathbf{2 a}, \mathbf{4}$ and $\mathbf{6}$.

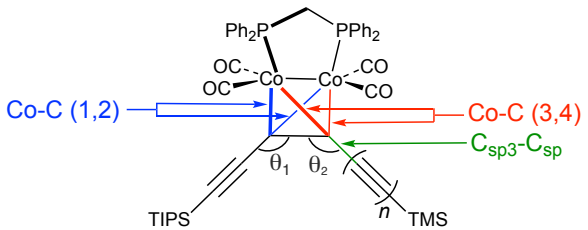

\begin{tabular}{|c|c|c|c|}
\hline Complex & 2 & 4 & 6 \\
\hline $\mathrm{Co}-\mathrm{C}(1) / \AA$ & $1.946(2)$ & $1.947(2)$ & $1.944(2)$ \\
\hline $\mathrm{Co}^{-} \mathrm{C}(2) / \AA$ & $1.949(2)$ & $1.947(3)$ & $1.953(2)$ \\
\hline Co-G $(3) / \AA$ & $1.956(2)$ & $1.952(2)$ & $1.958(2)$ \\
\hline $\mathrm{Co}^{-}-\mathrm{C}(4) / \AA$ & $1.963(2)$ & $1.954(2)$ & $1.958(2)$ \\
\hline $\mathrm{C}_{\mathrm{sp}}-\mathrm{C}_{\mathrm{sp} 3} / \AA$ & $1.409(3)$ & $1.391(3)$ & $1.381(2)$ \\
\hline $\mathrm{C} \equiv \mathrm{C} / \AA$ & $1.211(3)$ & $1.207(3)$ & $1.215(2)$ \\
\hline $\mathrm{C}-\mathrm{C} / \AA$ & N/A & $1.373(4)$ & $1.358(2)$ \\
\hline $\mathrm{C} \equiv \mathrm{C} / \AA$ & N/A & $1.207(4)$ & $1.214(2)$ \\
\hline $\mathrm{C}-\mathrm{C} / \AA$ & $\mathrm{N} / \mathrm{A}$ & $\mathrm{N} / \mathrm{A}$ & $1.365(2)$ \\
\hline $\mathrm{C} \equiv \mathrm{C} / \AA$ & N/A & N/A & $1.208(2)$ \\
\hline $\mathrm{C}-\mathrm{Si} / \AA$ & $1.839(3)$ & $1.842(3)$ & $1.852(2)$ \\
\hline Avg. BLA / Å & $\mathrm{N} / \mathrm{A}$ & $0.175(7)$ & $0.156(4)$ \\
\hline Avg. Co-G / Å & $1.953(2)$ & $1.950(2)$ & $1.953(2)$ \\
\hline$\theta_{1} / \circ$ & $146.3(2)$ & $137.5(2)$ & $138.0(2)$ \\
\hline$\theta_{2} / \circ$ & $136.8(2)$ & $139.1(2)$ & $143.6(2)$ \\
\hline$\angle \mathrm{C}_{\mathrm{Co}}-\mathrm{C} \equiv \mathrm{C} / \circ$ & $178.9(2)$ & $174.9(2)$ & $174.9(2)$ \\
\hline $\mathrm{C} \equiv \mathrm{C}-\mathrm{C} /{ }^{\circ}$ & $\mathrm{N} / \mathrm{A}$ & $175.6(2)$ & 178.1(2) \\
\hline $\mathrm{C}-\mathrm{C} \equiv \mathrm{C} /{ }^{\circ}$ & $\mathrm{N} / \mathrm{A}$ & $177.3(3)$ & 179.2(2) \\
\hline $\mathrm{C} \equiv \mathrm{C}-\mathrm{C} /{ }^{\circ}$ & $\mathrm{N} / \mathrm{A}$ & $\mathrm{N} / \mathrm{A}$ & $177.4(2)$ \\
\hline $\mathrm{C}-\mathrm{C} \equiv \mathrm{C} /{ }^{\circ}$ & $\mathrm{N} / \mathrm{A}$ & $\mathrm{N} / \mathrm{A}$ & $177.2(2)$ \\
\hline Avg. chain $/{ }^{\circ}$ & $178.9(2)$ & $175.9(2)$ & $177.4(2)$ \\
\hline
\end{tabular}

\section{CONCLUSIONS}

A series of cobalt complexes with masked alkyne $\pi$-systems have been synthesized. A synthetic route that yielded a series of dicobalt complexes with an exposed arm of one, two and three ethynyl units was followed. This series provided substrates for forming long masked polyynes and allowed a systematic investigation into optical and solid state properties of these structures. The absorption spectra of these complexes have been investigated. A charge transfer band between the polyyne and the dicobalt moiety is supported by DFT calculations and solvatochromism experiments.

Further chemistry with these cobalt complexes led to preparation, by Eglinton couplings, of tetracobalt masked TIPSendcapped polyynes of lengths up to the decayne. An unexpected isomerization during Eglinton coupling was discovered by crystallographic analysis. These structures could be readily unmasked with elemental iodine, offering the most facile method of unmasking long polyynes yet reported. This method offers promise for mild unmasking of supramolecular carbon-rich structures and other extended $\pi$-systems.

\section{EXPERIMENTAL}

General. Reagents (Acros, Aldrich, Fluorochem, and TCI) were purchased as reagent grade and used without further purification. Solvents for extraction or column chromatography were used in HPLC grade. Dry solvents (THF, $\mathrm{CH}_{2} \mathrm{Cl}_{2}, \mathrm{Et}_{2} \mathrm{O}$ ) for reactions were purified by the solvent drying system MBraun MB-SPS-5-Bench Top under nitrogen atmosphere $\left(\mathrm{H}_{2} \mathrm{O}\right.$ content $<20 \mathrm{ppm}$ as determined by Karl-Fischer titration). All other solvents were purchased in p.a. quality. Reactions in the absence of air and moisture were performed in oven-dried glassware under $\mathrm{Ar}$ or $\mathrm{N}_{2}$ atmosphere. Flash column chromatography was performed using $\mathrm{SiO}_{2}$ (60 $\AA$, 230-400 mesh, particle size $0.040-0.063 \mathrm{~mm}$, Merck) at $25{ }^{\circ} \mathrm{C}$ with a head pressure of $0.0-0.5$ bar. The used solvent compositions are reported individually in parentheses. Analytical thin layer chromatography (TLC) was performed on aluminum sheets coated with silica gel 60 F254 (Merck). Visualization was achieved using UV light (254 or $366 \mathrm{~nm}$ ) or by staining with iodine adsorbed on $\mathrm{SiO}_{2}$. Evaporation in vacuo was performed at 25-60 ${ }^{\circ} \mathrm{C}$ and 900-10 mbar. Reported yields refer to spectroscopically and chromatographically pure compounds that were dried under high vacuum $(0.1-0.05$ mbar) before analytical characterization. ${ }^{1} \mathrm{H}$ and ${ }^{13} \mathrm{C}$ nuclear magnetic resonance (NMR) spectra were recorded on Bruker AVIII HD 400 and AVIII HD 500 spectrometers at $400 \mathrm{MHz}, 500 \mathrm{MHz}$ $\left({ }^{1} \mathrm{H}\right)$ and $101 \mathrm{MHz}, 125 \mathrm{MHz}\left({ }^{13} \mathrm{C}\right)$, respectively. Temperatures of measurements are indicated in the procedures and on the spectra. Chemical shifts $\delta$ are reported in ppm downfield from tetramethylsilane using the residual deuterated solvent signals as an internal reference $\left(\mathrm{CDCl}_{3}: \delta_{\mathrm{H}}=7.26 \mathrm{ppm}, \delta_{\mathrm{C}}=77.0 \mathrm{ppm}\right)$. Melting points are uncorrected. MALDI-TOF mass spectrometry was conducted using a Micromass MALDI micro MX spectrometer in positive reflectron mode. Dithranol was used as the matrix unless stated otherwise. UV-vis spectra were recorded on a Perkin Elmer Lambda 20 at 298 K (240-700 nm) or a Perkin Elmer Lambda 1050 (240-700 nm). Elemental analysis was performed at London Metropolitan University with a Thermo (Carlo Erba) Flash 2000 Elemental Analyzer, configured for $\% \mathrm{CHN}$.

Tetracarbonyl $\left[\mu^{2}-(3,4-\eta: 3,4-\eta)\right.$-triisopropyl((trimethylsilyl)hexa1,3,5-triyn-1-yl) silane] [ $\mu$-methylenebis(diphenylphosphine)-P:P']dicobalt 2a. A solution of triyne $\mathbf{1}(1.22 \mathrm{~g}, 4.03 \mathrm{mmol})$ and $\mathrm{Co}_{2}(\mathrm{CO})_{8}$ $(1.52 \mathrm{~g}, 4.44 \mathrm{mmol})$ in $\mathrm{O}_{2}$-free hexane $(60 \mathrm{~mL})$ was stirred at 20 ${ }^{\circ} \mathrm{C}$ under $\mathrm{N}_{2}$ for $12 \mathrm{~h}$. The hexane was evaporated and the residue dissolved in dry toluene $(25 \mathrm{~mL})$. Bisdiphenylphosphinomethane $(1.60 \mathrm{~g}, 4.16 \mathrm{mmol})$ was added and the solution heated to reflux for $30 \mathrm{~min}$. The crude reaction mixture contained two products. Evaporation and column chromatography (hexane/ $\mathrm{CH}_{2} \mathrm{Cl}_{2} \quad$ 9:1 and 8:2) afforded intensely dark red crystals of $2 \mathbf{a}(0.98 \mathrm{~g}, 27 \%) ; R_{\mathrm{f}}=0.35$ (hexane), $\mathrm{mp} 181-185^{\circ} \mathrm{C}$ after recrystallization from $\mathrm{CH}_{2} \mathrm{Cl}_{2} / \mathrm{MeOH}$

${ }^{1}{ }_{H}$ NMR $\left(400 \mathrm{MHz}, \mathrm{CDCl}_{3}\right) \delta 0.26(\mathrm{~s}, 9 \mathrm{H}), 1.12-1.16(\mathrm{~m}, 21$ $\mathrm{H}, i$-Pr- $H), 3.34\left(\mathrm{q},{ }^{2} \mathcal{J}_{\mathrm{H}-\mathrm{P}}=10.9 \mathrm{~Hz}, 1 \mathrm{H}, \mathrm{PCHP}\right), 3.51\left(\mathrm{q},{ }^{2} \mathcal{J}_{\mathrm{H}-\mathrm{P}}=\right.$ $\left.10.9 \mathrm{~Hz}, 1 \mathrm{H}, \mathrm{PG} H^{\prime} \mathrm{P}\right), 7.15-7.20(\mathrm{~m}, 4 \mathrm{H}, H-\mathrm{Ar}), 7.21-7.31(\mathrm{~m}$, $8 \mathrm{H}, H-\mathrm{Ar}), 7.32-7.41 \mathrm{ppm}(\mathrm{m}, 8 \mathrm{H}, H-\mathrm{Ar}) .{ }^{13} \mathrm{C} \mathcal{N} M R(100 \mathrm{MHz}$, $\left.\mathrm{CDCl}_{3}\right) \delta 0.5,11.7,19.0,35.1\left(\mathrm{t}, 1_{\mathrm{C}-\mathrm{P}}=22.1 \mathrm{~Hz}\right), 68.9(b r), 71.5$ (br), 99.6, 102.3, 107.6, 109.6, 128.4-128.6 (m), 129.8 (s) 130.0 $(\mathrm{s}), 131.8\left(\mathrm{t},{ }^{3} \mathcal{F}_{\mathrm{C}-\mathrm{P}}=4.7 \mathrm{~Hz}\right), 132.4\left(\mathrm{t},{ }^{2} \mathcal{F}_{\mathrm{C}-\mathrm{P}}=5.1 \mathrm{~Hz}\right), 135.1(\mathrm{t}$, $\left.\mathcal{f}_{\mathrm{C}-\mathrm{P}}=19.1 \mathrm{~Hz}\right), 136.5\left(\mathrm{t}, \mathcal{F}_{\mathrm{C}-\mathrm{P}}=19.8 \mathrm{~Hz}\right), 202.3(b r), 203.8 \mathrm{ppm}$ (br). IR (ATR) $2105.1(\mathrm{C} \equiv \mathrm{C}), 2026.5(\mathrm{C}=\mathrm{O}), 1996.2(\mathrm{C}=\mathrm{O})$, $1973.2(\mathrm{C}=\mathrm{O}), 1956.0(\mathrm{C}=\mathrm{O}) \mathrm{cm}^{-1}$. MALDI MS 804.17 (Calc (- 
$4 \mathrm{CO}$ ). $\left.\left.\mathrm{C}_{43} \mathrm{H}_{52} \mathrm{Co}_{2} \mathrm{P}_{2} \mathrm{Si}_{2}\right)\right)$, 804.16 (-4 CO). Anal. Calcd for $\mathrm{C}_{47} \mathrm{H}_{52} \mathrm{Co}_{2} \mathrm{O}_{4} \mathrm{P}_{2} \mathrm{Si}_{2}$ : C, 61.57; H, 5.72 Found: C, 61.56; H, 5.75. UV-vis: $\left(\mathrm{CH}_{2} \mathrm{Cl}_{2}, 25^{\circ} \mathrm{C}\right) \lambda_{\max }(\log \varepsilon) 290 \mathrm{~nm}(4.40), 350 \mathrm{~nm}$ (3.99). Crystal Data: $\quad \mathrm{C}_{47} \mathrm{H}_{52} \mathrm{Co}_{2} \mathrm{O}_{4} \mathrm{P}_{2} \mathrm{Si}_{2}, \quad M_{r}=916.91 \quad(Z=4)$. Orthorhombic P2 ${ }_{1} 2{ }_{1}{ }_{1} ; a=14.1381(1) \AA, b=15.8779(1) \AA, c=$ 20.5634(2) $\AA, V=4616.14(6) \AA^{3}, R_{1}=0.0296, w R_{2}=0.0641(I$ $>2 \sigma(I)$.

Additionally, a regioisomer tetracarbonyl $\left[\mu^{2}-(5,6-\eta: 5,6-\eta)-\right.$ triisopropyl((trimethylsilyl)hexa-1,3,5-triyn-1-yl)silane] $[\mu-$ methylenebis(diphenylphosphine)-P:P'] dicobalt $\mathbf{2 b}$ was isolated from the same reaction and was characterized as dark red crystals $(1.63 \mathrm{~g}, 45 \%), R_{\mathrm{f}}=0.51$ (hexane); $\mathrm{mp} 181-183^{\circ} \mathrm{C}$. The structure of this regioisomer $\mathbf{2 b}$ was confirmed by $\mathrm{X}$-ray crystallographic analysis.

${ }^{1}{ }^{H} \mathcal{N M R}\left(400 \mathrm{MHz}, \mathrm{CDCl}_{3}\right) \delta 0.37(\mathrm{~s}, 9 \mathrm{H}), 1.16-1.21(\mathrm{~m}, 21$ $\mathrm{H}, i-\mathrm{Pr}-H), 3.27-3.32(\mathrm{~m}, \mathrm{PC} H \mathrm{P}), 3.94-4.03\left(\mathrm{~m}, 1 \mathrm{H}, \mathrm{PC} H^{\prime} \mathrm{P}\right)$, 7.12-7.16 (m, 4H, H-Ar), 7.21-7.24 (m, 2H, H-Ar), 7.27-7.34 (m, 10H, H-Ar), 7.39-7.49 ppm (m, 4H, H-Ar). ${ }^{13} \mathrm{C}$ NMR (100 $\left.\mathrm{MHz}_{1} \mathrm{CDCl}_{3}\right) \delta 0.9,11.8,19.1,38.6\left(\mathrm{t}, 1 \mathcal{F}_{\mathrm{C}-\mathrm{P}}=19.5 \mathrm{~Hz}\right), 75.0(\mathrm{t}$, ${ }^{2} \mathcal{F}_{\mathrm{C}-\mathrm{P}}=11.6 \mathrm{~Hz}$ ), $80.3\left(\mathrm{t},{ }^{3} \mathcal{F}_{\mathrm{C}-\mathrm{P}}=4.1 \mathrm{~Hz}\right), 81.7,88.5$ (satellite: $\mathrm{d}$, $1 \mathcal{F}_{\mathrm{C}-\mathrm{Si}}=77.1 \mathrm{~Hz}, 91.5\left(\mathrm{t}, 2 \mathcal{J}_{\mathrm{C}-\mathrm{P}}=7.7 \mathrm{~Hz}\right), 92.0,128.5\left(\mathrm{t}, 3 \mathcal{F}_{\mathrm{C}-\mathrm{P}}=\right.$ $4.8 \mathrm{~Hz}), 128.7\left(\mathrm{t},{ }^{3} \mathrm{~F}_{\mathrm{C}-\mathrm{P}}=4.7 \mathrm{~Hz}\right), 129.8(\mathrm{~s}) 130.1(\mathrm{~s}), 131.5\left(\mathrm{t},{ }^{2} \mathcal{J}_{\mathrm{C}}\right.$ $\mathrm{p}=6.4 \mathrm{~Hz}), 132.7\left(\mathrm{t},{ }^{2} \mathcal{F}_{\mathrm{C}-\mathrm{P}}=6.1 \mathrm{~Hz}\right), 135.2\left(\mathrm{t}, 1 \mathcal{F}_{\mathrm{C}-\mathrm{P}}=17.8 \mathrm{~Hz}\right)$, $137.1\left(\mathrm{t}, 1 \mathfrak{\mathcal { F }}_{\mathrm{C}-\mathrm{P}}=22.6 \mathrm{~Hz}\right), 201.4(b r), 207.2 \mathrm{ppm}(b r) . I R(A T R)$ : $2159.5(\mathrm{C} \equiv \mathrm{C}), 2024.5(\mathrm{C}=\mathrm{O}), 2001.2(\mathrm{C}=\mathrm{O}), 1973.2 \mathrm{~cm}^{-1}$ $(\mathrm{C}=\mathrm{O}) . M A L D I M S 804.17$ (Calc. (-4 CO) $\left.\mathrm{C}_{43} \mathrm{H}_{52} \mathrm{Co}_{2} \mathrm{P}_{2} \mathrm{Si}_{2}\right)$ ), 804.16 (-4 CO). Anal. Calcd for $\mathrm{C}_{47} \mathrm{H}_{52} \mathrm{Co}_{2} \mathrm{O}_{4} \mathrm{P}_{2} \mathrm{Si}_{2}\left(\mathrm{CH}_{2} \mathrm{Cl}_{2}\right)_{0.5}$ : C, 59.47; H, 5.57 Found: C, 59.15; H, 5.79 Crystal Data: $\mathrm{C}_{95} \mathrm{H}_{106} \mathrm{Cl}_{2} \mathrm{Co}_{4} \mathrm{O}_{8} \mathrm{P}_{4} \mathrm{Si}_{4}, \quad M_{r}=1918.76(Z=2)$. Monoclinic $\mathrm{P} 2{ }_{1} / \mathrm{n} ; a=17.1505(2) \AA, b=12.7684(2) \AA, c=22.9778(3) \AA, \beta$ $=106.2309(5)^{\circ}, V=4831.23(11) \AA^{3}, R_{1}=0.0348, w R_{2}=0.0748$ $(I>2 \sigma(I))$.

Tetracarbonyl $\left[\mu^{2}-(3,4-\eta: 3,4-\eta)\right.$-triisopropyl(hexa-1,3,5-triyn-1yl) silane] [ $\mu$-methylenebis(diphenylphosphine)-P:P'] dicobalt 3. A solution of cobalt complex $\mathbf{2 a}(67 \mathrm{mg}, 0.073 \mathrm{mmol})$ was dissolved in 1:1 $\mathrm{MeOH} / \mathrm{THF}$ mixture $(6 \mathrm{~mL}) . \mathrm{K}_{2} \mathrm{CO}_{3}(100 \mathrm{mg}, 0.73 \mathrm{mmol})$ was added in one portion. The reaction was stirred at $25{ }^{\circ} \mathrm{C}$ and monitored via TLC, completion occurred after $30 \mathrm{~min}$. The reaction mixture was evaporated and then dissolved in $\mathrm{CH}_{2} \mathrm{Cl}_{2}$ /petroleum ether (1:1) and filtered through $\mathrm{SiO}_{2}$ plug. Compound 3 was isolated as red crystals (57 mg, 96\%).

${ }^{1} H$ NMR $\left(400 \mathrm{MHz}, \mathrm{CDCl}_{3}\right) \delta$ 1.09-1.15 (m, $21 \mathrm{H}, i$-Pr- $H$ ), 3.34-3.50 (m, 2H, $\left.\mathrm{PCH} H_{2} \mathrm{P}\right), 3.71(\mathrm{~s}, 1 \mathrm{H}, \mathrm{C} \equiv \mathrm{C}-H), 7.11-7.18(\mathrm{~m}$, $4 \mathrm{H}, H-\mathrm{Ar}), 7.21-7.33$ (m, 8H, $H-\mathrm{Ar}), 7.38-7.45 \mathrm{ppm}(\mathrm{m}, 8 \mathrm{H}$, $H$-Ar). ${ }^{13} \mathrm{CNMR}\left(100 \mathrm{MHz}, \mathrm{CDCl}_{3}\right) \delta 11.8,19.1,35.5\left(\mathrm{t},{ }^{1} \mathcal{J}_{\mathrm{C}-\mathrm{P}}=\right.$ $21.9 \mathrm{~Hz}), 69.8(b r), 70.4(b r), 83.8,86.4,99.6,109.0,128.4\left(\mathrm{t}, 3_{\mathrm{G}} \mathrm{C}\right.$ $\left.{ }_{\mathrm{P}}=5.0 \mathrm{~Hz}\right), 128.7\left(\mathrm{t}, 3 \mathrm{~J}_{\mathrm{C}-\mathrm{P}}=5.0 \mathrm{~Hz}\right), 130.0(\mathrm{~s}) 130.2(\mathrm{~s}), 131.7(\mathrm{t}$, $\left.{ }^{2} \mathcal{F}_{\mathrm{C}-\mathrm{P}}=5.7 \mathrm{~Hz}\right), 132.5\left(\mathrm{t},{ }^{2} \mathcal{F}_{\mathrm{C}-\mathrm{P}}=5.1 \mathrm{~Hz}\right), 134.6\left(\mathrm{t},{ }^{1} \mathcal{F}_{\mathrm{C}-\mathrm{P}}=21.8\right.$ $\left.\mathrm{Hz}), 136.8\left(\mathrm{t}, 1 \mathcal{F}_{\mathrm{C}-\mathrm{P}}=23.1 \mathrm{~Hz}\right),\right), 202.2(b r), 204.0 \mathrm{ppm}(b r) . I R$ (ATR): $3306.4(\mathrm{C} \equiv \mathrm{C}-\mathrm{H}), 2105.7(\mathrm{C} \equiv \mathrm{C}), 2070.1(\mathrm{C} \equiv \mathrm{C}), 2033.1$ $(\mathrm{C}=\mathrm{O}), 2008.6(\mathrm{C}=\mathrm{O}), 1982.9 \mathrm{~cm}^{-1}(\mathrm{C}=\mathrm{O})$. MALDI MS 732.13 (Calc. $\mathrm{C}_{40} \mathrm{H}_{44} \mathrm{Co}_{2} \mathrm{P}_{2} \mathrm{Si}$ ), 732.90 (Found -4 CO).

Tetracarbonyl $\left[\mu^{2}-(3,4-\eta: 3,4-\eta)\right.$-triisopropyl((trimethylsilyl)octa1,3,5,7-tetrayn-1-yl)silane] [ $\mu$-methylenebis (diphenylphosphine)-

P:P'] dicobalt 4. Cobalt complex 3 (50 mg, $0.059 \mathrm{mmol})$, TMS acetylene (0.29 g, $0.406 \mathrm{~mL}, 2.95 \mathrm{mmol})$, CuCl (3.01 g, 30.4 mmol) were dissolved in $\mathrm{CH}_{2} \mathrm{Cl}_{2}(400 \mathrm{~mL})$ and stirred vigorously under dry air. TMEDA (3.22 g, $4.25 \mathrm{~mL}, 27.6 \mathrm{mmol})$ was added and the reaction was stirred vigorously for $2 \mathrm{~h}$. The reaction was quenched with water $(200 \mathrm{~mL})$, organic phase separated and washed again with water to remove $\mathrm{Cu}$ salts. The organic phase was concentrated in vacuo and then passed through a $\mathrm{SiO}_{2}$ plug to yield $\mathbf{4}$ as a red solid (42 mg, 82\%)

${ }^{1} H \mathcal{N} M R\left(400 \mathrm{MHz}, \mathrm{CDCl}_{3}\right) \delta 0.25(\mathrm{~s}, 9 \mathrm{H}), 1.08-1.12(\mathrm{~m}, 21$ $\mathrm{H}, i-\operatorname{Pr}-H), 3.36\left(\mathrm{q},{ }^{2} \mathcal{J}_{H-P}=10.5 \mathrm{~Hz}, 1 \mathrm{H}, \mathrm{PCHP}\right), 3.46\left(\mathrm{q},{ }^{2} \mathcal{J}_{H-P}=\right.$ $\left.10.9 \mathrm{~Hz}, 1 \mathrm{H}, \mathrm{PC} H^{\prime} \mathrm{P}\right), 7.09-7.12$ (m, 4H, H-Ar), 7.20-7.33 (m, 12H, $H-\mathrm{Ar}), 7.37-7.43 \mathrm{ppm}(\mathrm{m}, 4 \mathrm{H}, H-\mathrm{Ar}) .{ }^{13} \mathrm{C}$ NMR $(100$ $\left.\mathrm{MHz}_{\mathrm{CDCl}}\right) \delta 0.2,11.8,19.1,35.8\left(\mathrm{t}, 1 \mathcal{J}_{\mathrm{C}-\mathrm{P}}=22.4 \mathrm{~Hz}\right), 67.9$ $(b r), 70.6(b r), 80.9,81.2,86.3,88.3,100.5,108.8,128.6\left(\mathrm{t},{ }^{3} f_{\mathrm{C}-\mathrm{P}}\right.$ $=4.8 \mathrm{~Hz}), 128.8\left(\mathrm{t}, 3 \mathrm{f}_{\mathrm{C}-\mathrm{P}}=4.7 \mathrm{~Hz}\right), 130.0(\mathrm{~s}) 130.2(\mathrm{~s}), 131.6(\mathrm{t}$, $\left.{ }^{2} \mathcal{F}_{\mathrm{C}-\mathrm{P}}=5.4 \mathrm{~Hz}\right), 132.6\left(\mathrm{t},{ }^{2} \mathcal{F}_{\mathrm{C}-\mathrm{P}}=5.6 \mathrm{~Hz}\right), 134.0\left(\mathrm{t}, 1{ }^{\mathrm{C}-\mathrm{P}}=21.8\right.$ $\mathrm{Hz}), 136.9$ (t, $\left.1 \mathcal{J}_{\mathrm{C}-\mathrm{P}}=22.7 \mathrm{~Hz}\right), 201.6(b r), 204.0 \mathrm{ppm}(b r) . I R$ (ATR): $2156.0(\mathrm{C} \equiv \mathrm{C}), 2105.8(\mathrm{C} \equiv \mathrm{C}), 2038.3(\mathrm{C}=\mathrm{O}), 2018.5$ $(\mathrm{C}=\mathrm{O}), 1986.5(\mathrm{C}=\mathrm{O}), 1960.7 \mathrm{~cm}^{-1}(\mathrm{C}=\mathrm{O})$. MALDI MS 828.17 (Calc. (-4 CO) $\left.\left.\mathrm{C}_{45} \mathrm{H}_{52} \mathrm{Co}_{2} \mathrm{P}_{2} \mathrm{Si}_{2}\right)\right), 828.17$ (-4 $\left.\mathrm{CO}\right)$. UV-vis: $\left(\mathrm{CH}_{2} \mathrm{Cl}_{2}, 25^{\circ} \mathrm{C}\right) \lambda_{\max }(\log \varepsilon) 304 \mathrm{~nm}(4.36), 372 \mathrm{~nm}$ (3.90). Crystal Data: $\mathrm{C}_{49} \mathrm{H}_{52} \mathrm{Co}_{2} \mathrm{O}_{4} \mathrm{P}_{2} \mathrm{Si}_{2}, M_{r}=940.93(Z=2)$. Triclinic P1; $a=$ 11.5356(2) $\AA, \quad b=12.1471(2) \AA, \quad c=19.7928(3) \AA, \quad \alpha=$ $76.0952(6)^{\circ}, \quad \beta=81.4150(7)^{\circ}, \quad \gamma=64.0407(6)^{\circ}, \quad V=$ $2417.46(7) \AA^{3}, R_{1}=0.0382, w R_{2}=0.0755(I>2 \sigma(I))$.

Tetracarbonyl $\left[\mu^{2}-(3,4-\eta: 3,4-\eta)\right.$-triisopropyl(octa-1,3,5,7-tetrayn-1$y$ l) silane] [ $\mu$-methylenebis(diphenylphosphine)-P:P']dicobalt 5. A solution of cobalt complex 4 (30 mg, $0.039 \mathrm{mmol})$ was dissolved in 1:1 $\mathrm{MeOH} / \mathrm{THF}$ mixture $(6 \mathrm{~mL}) . \mathrm{K}_{2} \mathrm{CO}_{3}(52.5 \mathrm{mg}, 0.38 \mathrm{mmol})$ was added in one portion. The reaction was stirred at $25^{\circ} \mathrm{C}$ and monitored via TLC, completion occurred after $30 \mathrm{~min}$. The reaction mixture was evaporated and then dissolved in $\mathrm{CH}_{2} \mathrm{Cl}_{2}$ /petroleum ether $(1: 1)$ and poured over a silica plug. Complex 5 was isolated as red crystals (26 mg, 100\%); mp 85 ${ }^{\circ} \mathrm{C}$ (decomposition).

${ }^{1} H$ NMR (400 MHz, $\left.\mathrm{CDCl}_{3}\right) \delta$ 1.10-1.14 (m, $21 \mathrm{H}, i$-Pr- $\left.H\right)$, $2.80(\mathrm{~s}, 1 \mathrm{H}, \mathrm{C} \equiv \mathrm{C}-H), 3.41\left(\mathrm{~m}, 2 \mathrm{H}, \mathrm{PCH}_{2} \mathrm{P}\right), 7.13-7.17(\mathrm{~m}, 4 \mathrm{H}$, $H$-Ar), 7.20-7.33 (m, 12H, H-Ar), 7.38-7.43 ppm (m, 4H, $H_{-}$ Ar). ${ }^{13} \mathrm{C} \mathcal{N M R}\left(100 \mathrm{MHz}, \mathrm{CDCl}_{3}\right) \delta 11.8,19.1,36.1\left(\mathrm{t}, 1{ }^{\mathrm{C}-\mathrm{P}}=\right.$ $22.4 \mathrm{~Hz}), 70.7,72.9,79.6,80.1,100.6,108.8,128.6\left(\mathrm{t}, 37_{\mathrm{C}-\mathrm{P}}=\right.$ $4.8 \mathrm{~Hz}), 128.8\left(\mathrm{t}, 3_{\mathrm{C}-\mathrm{P}}=4.7 \mathrm{~Hz}\right), 130.1(\mathrm{~s}) 130.3(\mathrm{~s}), 131.6\left(\mathrm{t},{ }^{2} \mathcal{F}_{\mathrm{C}-}\right.$ $\mathrm{p}=5.4 \mathrm{~Hz}), 132.6\left(\mathrm{t},{ }^{2} \mathcal{F}_{\mathrm{C}-\mathrm{P}}=5.6 \mathrm{~Hz}\right), 134.1(b r), 136.9(b r), 201.9$ (br), $203.6 \mathrm{ppm}(b r) . I R(A T R): 3305.1(\mathrm{C} \equiv \mathrm{C}-\mathrm{H}), 2161.3(\mathrm{C} \equiv \mathrm{C})$, $2102.0(\mathrm{C} \equiv \mathrm{C}), 2034.8(\mathrm{C}=\mathrm{O}), 2010.0(\mathrm{C}=\mathrm{O}), 1985.0 \mathrm{~cm}^{-1}$ $(\mathrm{C}=\mathrm{O})$.

Tetracarbonyl $\left[\mu^{2}-(3,4-\eta: 3,4-\eta)\right.$-triisopropyl((trimethylsilyl)deca1,3,5, 7,9-pentayn-1-yl)silane] [ $\mu$-methylenebis(diphenylphosphine)-

P:P'] dicobalt 6. Cobalt complex 5 (100 mg, $0.12 \mathrm{mmol})$, TMS acetylene $(0.580 \mathrm{~g}, 0.813 \mathrm{~mL}, 5.90 \mathrm{mmol}), \mathrm{CuCl}(1.17 \mathrm{~g}, 11.8$ mmol) were dissolved in $\mathrm{CH}_{2} \mathrm{Cl}_{2}(400 \mathrm{~mL})$ and stirred vigorously under dry air. TMEDA (1.68 mL, $11.7 \mathrm{mmol})$ was added and the reaction mixture was stirred for 40 mins. The reaction was quenched with water $(200 \mathrm{~mL})$, organic phase separated and washed again with water $(150 \mathrm{~mL})$ to remove $\mathrm{Cu}$ salts. The organic phase was reduced in vacuo and then passed through a $\mathrm{SiO}_{2}$ plug to yield 6 as a red solid (84 mg, 82\%); mp $150{ }^{\circ} \mathrm{C}$ (decomposition).

${ }^{1} H \mathcal{N} M R\left(400 \mathrm{MHz}, \mathrm{CDCl}_{3}\right) \delta 0.24(\mathrm{~s}, 9 \mathrm{H}), 1.08-1.13(\mathrm{~m}, 21$ $\mathrm{H}, i$-Pr- $H$ ), 3.35-3.42, m, 2H, PCH $\left.H_{2} \mathrm{P}\right), 7.11-7.129\left(\mathrm{~m}, 4 \mathrm{H}, H_{-}\right.$ Ar), 7.22-7.33 (m, 12H, H-Ar), 7.37-7.43 ppm (m, 4H, H-Ar). ${ }^{13} \mathrm{C} \mathcal{N M R}\left(100 \mathrm{MHz}, \mathrm{CDCl}_{3}\right) \delta 0.0,11.8,19.1,36.3\left(\mathrm{t}, 1{ }_{\mathrm{C}-\mathrm{P}}=\right.$ $20.5 \mathrm{~Hz}), 64.4,66.1(b r), 68.9,72.3(b r), 81.1,82.1,89.7,89.8$, 101.2, 108.9, 128.7 (t, $\left.3 \mathcal{F}_{\mathrm{C}-\mathrm{P}}=4.7 \mathrm{~Hz}\right), 128.8\left(\mathrm{t}, 3 \mathcal{f}_{\mathrm{C}-\mathrm{P}}=4.9 \mathrm{~Hz}\right)$, $130.2(\mathrm{~s}) 130.4(\mathrm{~s}), 131.7\left(\mathrm{t}, 2 \mathcal{F}_{\mathrm{C}-\mathrm{P}}=6.0 \mathrm{~Hz}\right), 132.5\left(\mathrm{t},{ }^{2} \mathcal{F}_{\mathrm{C}-\mathrm{P}}=5.7\right.$ $\mathrm{Hz}), 134.1\left(\mathrm{t}, 1 \mathcal{J}_{\mathrm{C}-\mathrm{P}}=20.8 \mathrm{~Hz}\right), 136.9\left(\mathrm{t}, 1 \mathcal{J}_{\mathrm{C}-\mathrm{P}}=21.5 \mathrm{~Hz}\right), 201.8$ (br), $203.3 \mathrm{ppm}(b r) . I R(A T R): 2126.4(\mathrm{C} \equiv \mathrm{C}), 2054.6(\mathrm{C}=\mathrm{O})$, $2035.9(\mathrm{C}=\mathrm{O}), 2014.9(\mathrm{C}=\mathrm{O}), 1991.5 \mathrm{~cm}^{-1}(\mathrm{C}=\mathrm{O})$. MALDI MS 852.17 (Calc. $\mathrm{C}_{47} \mathrm{H}_{52} \mathrm{Co}_{2} \mathrm{P}_{2} \mathrm{Si}_{2}$ ), 853.95 (-4 $\left.\mathrm{CO}\right)$. UV-vis: 
$\left(\mathrm{CH}_{2} \mathrm{Cl}_{2}, 25^{\circ} \mathrm{C}\right) \lambda_{\max }(\log \varepsilon) 342 \mathrm{~nm}(4.20), 417 \mathrm{~nm}$ (3.55). Crystal Data: $\mathrm{C}_{51} \mathrm{H}_{52} \mathrm{Co}_{2} \mathrm{O}_{4} \mathrm{P}_{2} \mathrm{Si}_{2}, M_{\mathrm{r}}=964.96(\mathrm{Z}=2)$. Triclinic P1; $a=$ 12.9206(2) $\AA, \quad b=13.1057(2) \AA, \quad c=17.0055(3) \AA, \quad \alpha=$ $104.4641(7)^{\circ}, \quad \beta=100.3881(8)^{\circ}, \quad \gamma=111.9056(9)^{\circ}, \quad V=$ $2464.22(7) \AA^{3}, R_{1}=0.0357, w R_{2}=0.0837(I>2 \sigma(I))$.

Tetracarbonyl $\left[\mu^{2}-(3,4-\eta: 3,4-\eta)\right.$-triisopropyl(deca-1,3,5, 7,9-pentayn1-yl)silane][ $\mu$-methylenebis(diphenylphosphine)-P:P']dicobalt 7. A solution of cobalt complex $6(50 \mathrm{mg}, 0.052 \mathrm{mmol})$ was dissolved in 1:1 $\mathrm{MeOH} / \mathrm{THF}$ mixture $(6 \mathrm{~mL}) . \mathrm{K}_{2} \mathrm{CO}_{3}(65 \mathrm{mg}, 0.47$ $\mathrm{mmol}$ ) was added in one portion. The reaction was stirred at $25^{\circ} \mathrm{C}$ and monitored via TLG, completion occurred after 30 mins. The solvents were evaporated and the residue dissolved in $\mathrm{CH}_{2} \mathrm{Cl}_{2}$ /petroleum ether $(1: 1)$ and filtered through a $\mathrm{SiO}_{2}$ plug. Compound 7 was isolated as red crystals (40 mg, 90\%).

${ }^{1} H$ NMR (400 MHz, $\left.\mathrm{CDCl}_{3}\right) \delta$ 1.07-1.13 (m, $21 \mathrm{H}, i$-Pr-H), $2.43(\mathrm{~s}, 1 \mathrm{H}, \mathrm{C} \equiv \mathrm{C}-H), 3.41$ (q, $\left.{ }^{2} \mathcal{J}_{H-P}=10.9 \mathrm{~Hz}, 2 \mathrm{H}, \mathrm{PCH}_{2} \mathrm{P}\right)$, 7.11-7.17 (m, 4H, H-Ar), 7.22-7.33 (m, 12H, H-Ar), 7.37$7.43 \mathrm{ppm}(\mathrm{m}, 4 \mathrm{H}, H-\mathrm{Ar}) .{ }^{13} \mathrm{C} N \mathrm{~N} R\left(100 \mathrm{MHz} \mathrm{CDCl}_{3}\right) \delta 11.7$, 19.0, $36.4\left(\mathrm{t},{ }^{1} \mathcal{F}_{\mathrm{C}-\mathrm{P}}=20.5 \mathrm{~Hz}\right), 62.9,68.2,69.7,70.0,80.6,81.2$, 101.1, 108.6, $128.5\left(\mathrm{t}, 3 \mathrm{f}_{\mathrm{C}-\mathrm{P}}=4.7 \mathrm{~Hz}\right), 128.7\left(\mathrm{t}, 3 \mathcal{f}_{\mathrm{C}-\mathrm{P}}=4.9 \mathrm{~Hz}\right)$, $130.0(\mathrm{~s}) 130.3(\mathrm{~s}), 131.5\left(\mathrm{t},{ }^{2} \mathrm{~F}_{\mathrm{C}-\mathrm{P}}=6.0 \mathrm{~Hz}\right), 132.4\left(\mathrm{t},{ }^{2} \mathcal{F}_{\mathrm{C}-\mathrm{P}}=5.7\right.$ $\mathrm{Hz}), 133.9$ (br), 136.7 (br), 201.8 (br), 203.3 ppm (br). IR (ATR): $3296.6(\mathrm{C} \equiv \mathrm{C}-\mathrm{H}), 2131.8(\mathrm{C} \equiv \mathrm{C}), 2033.0(\mathrm{C}=\mathrm{O}), 2003.6(\mathrm{C}=\mathrm{O})$, $1988.9(\mathrm{C}=\mathrm{O}), 1963.9 \mathrm{~cm}^{-1}(\mathrm{C}=\mathrm{O})$.

Octacarbonylbis $\left[\mu\right.$-methylenebis (diphenylphosphine)-P:P'] $\left[\mu^{4-(3,4-}\right.$ $\eta: 3,4-\eta ; 9,10-\eta: 9,10-\eta)-(1,12$-bis(triisopropylsilyl)-1,3,5,7,9,11-

dodecahexayne)] tetracobalt $\mathbf{8 a}$. Mono-TIPS acetylene Co complex 3 (40 mg, $47.3 \mu \mathrm{mol})$ was dissolved in dry pyridine $(3 \mathrm{~mL}$ ). $\mathrm{Cu}(\mathrm{OAc})_{2}(86 \mathrm{mg}, 473 \mu \mathrm{mol})$ was added under $\mathrm{N}_{2}$ and stirred overnight at $25^{\circ} \mathrm{C}$. Pyridine was removed in vacuo. This yielded two products, which were separated via column chromatography $\left(\mathrm{CH}_{2} \mathrm{Cl}_{2}\right.$ /petroleum ether 9:1). The higher $R_{\mathrm{f}}$ product $\mathbf{8 a}$ was isolated as a brown solid (32 $\mathrm{mg}, 80 \%)$.

${ }^{1} H$ NMR $\left(400 \mathrm{MHz}, \mathrm{CDCl}_{3}\right) \delta 1.09-1.13$ (m, 42H, $i$-Pr- $\left.H\right)$, $3.40\left(\mathrm{t},{ }^{2} \mathcal{F}_{\mathrm{H}-\mathrm{P}}=10.3 \mathrm{~Hz}, 2 \mathrm{H}, \mathrm{PC} H_{2} \mathrm{P}\right), 7.11-7.18(\mathrm{~m}, 8 \mathrm{H}, H-\mathrm{Ar})$, 7.21-7.33 (m, 24H, $H-\mathrm{Ar}$ ), 7.38-7.45 ppm (m, 8H, $H-\mathrm{Ar}) .{ }^{13} \mathrm{C}$ $\mathcal{N M R}\left(100 \mathrm{MHz}, \mathrm{CDCl}_{3}\right) \delta 11.8,19.1,35.5\left(\mathrm{t}, 1 \mathcal{f}_{\mathrm{C}-\mathrm{P}}=21.9 \mathrm{~Hz}\right)$, $68.8(b r), 71.4(b r), 84.4,87.6,100.5,108.2,128.4-128.6(\mathrm{~m})$, $129.9(\mathrm{~s}) 130.2(\mathrm{~s}), 131.7\left(\mathrm{t},{ }^{2} \mathcal{F}_{\mathrm{C}-\mathrm{P}}=5.7 \mathrm{~Hz}\right), 132.3\left(\mathrm{t},{ }^{2} \mathcal{F}_{\mathrm{C}-\mathrm{P}}=5.1\right.$ $\mathrm{Hz}), 134.3\left(\mathrm{t}, 1 \mathcal{F}_{\mathrm{C}-\mathrm{P}}=21.8 \mathrm{~Hz}\right), 136.6\left(\mathrm{t}, 1_{\mathrm{C}-\mathrm{P}}=23.1 \mathrm{~Hz}\right), 203.1$ ppm (br). IR (ATR): $2169.9(\mathrm{C} \equiv \mathrm{C}), 2079.5(\mathrm{C} \equiv \mathrm{C}), 2034.5$ $(\mathrm{C}=\mathrm{O}), 2013.8(\mathrm{C}=\mathrm{O}), 1989.5 \mathrm{~cm}^{-1}(\mathrm{C}=\mathrm{O})$. Anal. Calcd for $\mathrm{C}_{88} \mathrm{H}_{86} \mathrm{Co}_{4} \mathrm{O}_{8} \mathrm{P}_{4} \mathrm{Si}_{2}: \mathrm{C}, 62.64 ; \mathrm{H}, 5.14$. Found: C, 62.57; H, 5.31. UV-Vis: $\lambda_{\max }(\log \varepsilon) 270 \mathrm{~nm}$ (4.65), $361 \mathrm{~nm}(4.52), 378 \mathrm{~nm}$ (4.53). Crystal Data: $\mathrm{C}_{88} \mathrm{H}_{86} \mathrm{Co}_{4} \mathrm{O}_{8} \mathrm{P}_{4} \mathrm{Si}_{2}, M_{\mathrm{r}}=1687.44(z=1)$. Triclinic P1; $a=11.5368(11) \AA, b=12.2121(10) \AA, c=$ $17.3928(18) \AA, \alpha=82.618(7)^{\circ}, \beta=84.683(8)^{\circ}, \gamma=81.577(7)^{\circ}, V$ $=2397.1(4) \AA^{3}, R_{1}=0.0542, w R_{2}=0.1031(I>2 \sigma(I))$.

The lower $R_{\mathrm{f}}$ product octacarbonylbis $[\mu-$ methylenebis(diphenylphosphine)-P:P'] [ $\mu^{4}-1,2-\eta: 1,2-\eta ; 11,12-$ $\eta: 11,12-\eta)-(1,12$-bis(triisopropylsilyl)-1,3,5,7,9,11-

dodecahexayne)] tetracobalt $\mathbf{8 b}$ was isolated as a red-brown solid (3 mg, 7\%)

${ }^{1} \mathrm{H} \mathrm{NMR}_{\left(400 \mathrm{MHz}, \mathrm{CDCl}_{3}\right) \delta}$ 1.09-1.13 (m, 42H, $i$-Pr-H), $3.40\left(\mathrm{t},{ }^{2} \mathrm{~J}_{\mathrm{H}-\mathrm{P}}=10.3 \mathrm{~Hz}, 4 \mathrm{H}, \mathrm{PC} H_{2} \mathrm{P}\right), 7.11-7.18(\mathrm{~m}, 8 \mathrm{H}, H-\mathrm{Ar})$, 7.21-7.33 (m, 24H, H-Ar), 7.38-7.45 ppm (m, 8H, H-Ar). Crystal Data: $\mathrm{C}_{88} \mathrm{H}_{87} \mathrm{Co}_{4} \mathrm{O}_{8} \mathrm{P}_{4} \mathrm{Si}_{2}, \quad M_{\mathrm{r}}=1688.45 \quad(Z=4)$. Monoclinic $\mathrm{P} 2{ }_{1} / \mathrm{n} ; a=14.4102(5) \AA, b=16.2137(7) \AA, c=$ $37.474(2) \AA, \beta=98.528(5)^{\circ}, V=8658.7(7) \AA^{3}, R_{1}=0.0348, w R_{2}$ $=0.0748(I>2 \sigma(I))$.
Octacarbonylbis $\left[\mu\right.$-methylenebis(diphenylphosphine)-P:P'] $\mu^{4-(3,4-}$ $\eta: 3,4-\eta ; 13,14-\eta: 13,14-\eta)-1,16$-bis(triisopropylsilyl)-

1,3,5,7,9,11,13,15-hexadecaoctayne]tetracobalt 9. Mono-TIPS

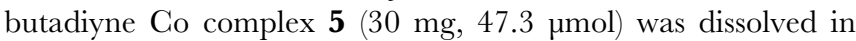
dry pyridine $(3 \mathrm{~mL}) \cdot \mathrm{Cu}(\mathrm{OAc})_{2}(75 \mathrm{mg}, 473 \mu \mathrm{mol})$ was added under $\mathrm{N}_{2}$ and stirred overnight at $25{ }^{\circ} \mathrm{C}$. The pyridine was removed in vacuo. This yielded two products which were separated by column chromatography $\left(\mathrm{CH}_{2} \mathrm{Cl}_{2} /\right.$ petroleum ether 9:1). The lower $R_{\mathrm{f}}$ product 9 was isolated as a brown solid (23 mg, 77\%); mp $110^{\circ} \mathrm{C}$ (decomposition).

${ }^{1} H$ NMR $\left(400 \mathrm{MHz}^{\mathrm{CDCl}}{ }_{3}\right) \delta 1.09-1.14(\mathrm{~m}, 42 \mathrm{H}, i$-Pr- $H)$, 3.36-3.43 (m, 4H, $\left.\mathrm{PCH} H_{2} \mathrm{P}\right), 7.13-7.18$ (m, 8H, H-Ar), 7.23$7.36(\mathrm{~m}, 24 \mathrm{H}, H-\mathrm{Ar}), 7.38-7.42$ (m, 8H, $H-\mathrm{Ar}) \mathrm{ppm} .{ }^{13} \mathrm{C}$ NMR $\left(100 \mathrm{MHz} \mathrm{CDCl}_{3}\right) \delta 11.9,19.1,36.3\left(\mathrm{t},{ }^{1} \mathcal{F}_{\mathrm{C}-\mathrm{P}}=21.9 \mathrm{~Hz}\right), 67.1$, 70.8, 82.4, 83.3, 101.3, 108.7, 128.5-128.8 (m), 130.0 (s) 130.2 $(\mathrm{s}), 131.6\left(\mathrm{t},{ }^{2} \mathrm{~F}_{\mathrm{C}-\mathrm{P}}=5.7 \mathrm{~Hz}\right), 132.3\left(\mathrm{t},{ }^{2} \mathrm{~F}_{\mathrm{C}-\mathrm{P}}=5.1 \mathrm{~Hz}\right), 134.1(\mathrm{t}$, $\left.1 \mathcal{F}_{\mathrm{C}-\mathrm{P}}=21.8 \mathrm{~Hz}\right), 136.3\left(\mathrm{t}, 1 \mathcal{F}_{\mathrm{C}-\mathrm{P}}=23.1 \mathrm{~Hz}\right), 201.7(b r), 202.9(b r)$ ppm. IR (ATR): $2148.8(\mathrm{C} \equiv \mathrm{C}), 2079.5,2034.5(\mathrm{C}=\mathrm{O}), 2013.8$ $(\mathrm{C}=\mathrm{O}), 1987.8 \mathrm{~cm}^{-1}(\mathrm{C}=\mathrm{O}) . U V$-vis: $\left(\mathrm{CH}_{2} \mathrm{Cl}_{2}, 25^{\circ} \mathrm{C}\right) \lambda_{\max }(\log \varepsilon)$ $285 \mathrm{~nm}$ (4.64), $385 \mathrm{~nm}$ (4.61), $409 \mathrm{~nm}$ (4.62).

Octacarbonylbis $\left[\mu\right.$-methylenebis (diphenylphosphine)-P:P'] $\left[\mu^{4-}(3,4-\right.$ $\eta: 3,4-\eta ; 17,18-\eta: 17,18-\eta)-(1,20-$ bis(triisopropylsilyl)-

1,3,5,7,9,11,13,15,17,19-einacosadecayne)]tetracobalt $\mathbf{1 0}$. MonoTIPS hexatriyne Co complex 7 (100 mg, $157 \mu \mathrm{mol})$ was dissolved in dry pyridine $(12 \mathrm{~mL}) . \mathrm{Cu}(\mathrm{OAc})_{2}(225 \mathrm{mg}, 0.142$ mmol) was added under $\mathrm{N}_{2}$ and stirred overnight at $25^{\circ} \mathrm{C}$. The pyridine was removed in vacuo. This yielded two products, which were separated via column chromatography $\left(\mathrm{CH}_{2} \mathrm{Cl}_{2}\right.$ /petroleum ether 9:1). The lower $R_{\mathrm{f}}$ product $\mathbf{1 0}$ was isolated as a brown solid (74 mg, 75\%).

${ }^{1} H$ NMR (400 MHz, $\left.\mathrm{CDCl}_{3}\right) \delta 1.09-1.12(\mathrm{~m}, 42 \mathrm{H}, i$-Pr- $H)$, $3.40\left(\mathrm{t},{ }^{2} \mathcal{J}_{\mathrm{H}-\mathrm{P}}=10.8 \mathrm{~Hz}, 4 \mathrm{H}, \mathrm{PC} H_{2} \mathrm{P}\right), 7.10-7.40\left(\mathrm{~m}, 40 \mathrm{H}, \mathrm{H}^{-}\right.$ Ar) ppm. ${ }^{13} C \mathcal{N M R}\left(100 \mathrm{MHz}, \mathrm{CDCl}_{3}\right) \delta$ 11.6, 19.0, 36.4-36.6 (m), 65.0, 65.6, 66.7, 69.9, 81.3, 83.3, 101.6, 108.5, 128.4-128.8 $(\mathrm{m}), 130.0(\mathrm{~s}) 130.3(\mathrm{~s}), 131.5\left(\mathrm{t},{ }^{2} \mathcal{J}_{\mathrm{C}-\mathrm{P}}=5.7 \mathrm{~Hz}\right), 132.2\left(\mathrm{t},{ }^{2} \mathrm{f}_{\mathrm{C}-\mathrm{P}}=\right.$ $5.1 \mathrm{~Hz}), 133.6-134.2(\mathrm{~m}), 136.2-136.3(\mathrm{~m}), 200.5(b r), 203.1(b r)$ ppm. IR (ATR): $2092.4(\mathrm{C} \equiv \mathrm{C}), 2008.6(\mathrm{C}=\mathrm{O}), 1991.9(\mathrm{C}=\mathrm{O})$, $1970.9 \mathrm{~cm}^{-1}(\mathrm{C}=\mathrm{O}) . U V$-vis: $\left(\mathrm{CH}_{2} \mathrm{Cl}_{2}, 25^{\circ} \mathrm{C}\right) \lambda_{\max }(\log \varepsilon) 285 \mathrm{~nm}$ (4.64), $385 \mathrm{~nm}$ (4.61), $409 \mathrm{~nm}$ (4.62).

1,12-Bis(triisopropylsilyl)-1,3,5,7,9,11-dodecahexayne

11. Tetracobalt masked hexayne $\mathbf{8 a}(50 \mathrm{mg}, 29 \mu \mathrm{mol})$ was dissolved in $\mathrm{THF}(3 \mathrm{~mL}), \mathrm{I}_{2}(37.0 \mathrm{mg}, 144 \mu \mathrm{mol})$ was added and the reaction mixture was stirred for $3 \mathrm{~h}$ at $25^{\circ} \mathrm{C}$. After completion was observed by TLC chromatography, the reaction mixture was filtered through a $\mathrm{SiO}_{2}$ plug (petroleum ether). This yielded a pale yellow solution, which was confirmed to contain the desired hexayne using UV-vis spectroscopy. The hexayne 11 was isolated as a yellow solid $(7.3 \mathrm{mg}, 55 \%)$. As in lit. ${ }^{33}$

${ }^{1} \mathrm{H} \mathcal{N M R}\left(500 \mathrm{MHz}, \mathrm{CDCl}_{3}\right) \delta 1.09(\mathrm{~s}, 42 \mathrm{H}){ }^{13} \mathrm{C} \mathcal{N} M R(125$ $\left.\mathrm{MHz}, \mathrm{CDCl}_{3}\right) \delta 11.8,18.7,61.2,62.5,62.8,63.0,87.9,89.5$ ppm.

1,16-Bis(triisopropylsilyl)-1,3,5,7,9,11,13,15-hexadecaoctayne 12. Tetracobalt masked octayne $\mathbf{9}(25 \mathrm{mg}, 14 \mu \mathrm{mol})$ was dissolved in THF $(10 \mathrm{~mL}), \mathrm{I}_{2}(18 \mathrm{mg}, 70 \mu \mathrm{mol})$ was added and the reaction mixture was stirred for $3 \mathrm{~h}$ at $25^{\circ} \mathrm{C}$. After completion was observed by TLC chromatography, the reaction mixture was filtered through a $\mathrm{SiO}_{2}$ plug (petroleum ether). This yielded a yellow solution, which was confirmed to contain the desired octayne using UV-vis spectroscopy. The octayne $\mathbf{1 2}$ was isolated as a yellow solid (3.2 mg, 45\%). As in lit. 33 
${ }^{1} \mathrm{H} \mathrm{NMR}\left(500 \mathrm{MHz}, \mathrm{CDCl}_{3}\right) \delta 1.08(\mathrm{~s}, 42 \mathrm{H}) .{ }^{13} \mathrm{C}$ NMR $(125$ $\left.\mathrm{MHz}_{\mathrm{CDCl}}\right) \delta 11.7,18.7,61.1,62.3,62.6,63.1,63.4,63.4$, 88.5, $89.4 \mathrm{ppm}$.

\section{1,20-Bis(triisopropylsilyl)-1,3,5,7,9,11,13,15,17,19-}

einacosadecayne 13. Tetracobalt masked decayne $10(50 \mathrm{mg}$, $28.0 \mu \mathrm{mol})$ was dissolved in THF $(10 \mathrm{~mL}), \mathrm{I}_{2}(10 \mathrm{mg})$ was added and the reaction mixture was stirred for $3 \mathrm{~h}$ at $25{ }^{\circ} \mathrm{C}$. After completion was observed by TLC chromatography, the reaction mixture was filtered through a $\mathrm{SiO}_{2}$ plug (petroleum ether). This yielded an orange solution, which was confirmed to contain the desired decayne using UV-vis spectroscopy. The decayne 13 was isolated as an orange solid $(6.0 \mathrm{mg}, 39 \%)$. As in lit. ${ }^{33}$

${ }^{1} \mathrm{H} \mathrm{NMR}\left(500 \mathrm{MHz}, \mathrm{CDCl}_{3}\right) \delta 1.08(\mathrm{~s}, 42 \mathrm{H}) .{ }^{13} \mathrm{C} \mathcal{N} M R(125$ $\left.\mathrm{MHz}_{2} \mathrm{CDCl}_{3}\right) \delta 11.7,18.7,61.0,62.2,62.9,63.2,63.5,63.8$, 88.8, $89.3 \mathrm{ppm}$.

\section{ASSOGIATED GONTENT}

\section{Supporting Information}

The Supporting Information is available free of charge on the ACS Publications website at DOI:

Supplementary NMR figures, electronic structure calculations, additional experiments, characterization spectra, and crystallography data (PDF)

DFT Cartesian coordinates (ZIP)

X-ray crystallographic data for compounds $2 \mathbf{a}, 2 \mathbf{2 b}, \mathbf{4}, \mathbf{6}, \mathbf{8 a}, \mathbf{8 b}, \mathbf{S 6}$

\section{AUTHOR INFORMATION}

\section{Corresponding Author}

* Email: harry.anderson@chem.ox.ac.uk

\section{AGKNOWLEDGMENT}

We thank the EPSRC and the European Research Council (Grant no. 320969) for funding, the University of Oxford Advanced Research Computing Service (ARG) for support (DOI:10.5281/zenodo.22558) and Diamond Light Source for beamtime (MT13629). P.G. acknowledges the receipt of an Early Postdoc.Mobility fellowship from the Swiss National Science Foundation. We thank Dr. A. L. Thompson for valuable discussion.

\section{REFERENGES}

(1) a) Hoye, T. R.; Baire, B.; Niu, D.; Willoughby, P. H.; Woods, B. P. Nature 2012, 490, 208. b) Cook, C. L.; Jones, E. R. H.; Whiting, M. C. 7. Chem Soc. 1952, 2883. c) de Meijere, A.; Kozhushkov, S.; Puls, C.; Haumann, T.; Boese, R.; Cooney. M. J.; Scott. L. T. Angew. Chem. Int. Ed. Engl. 1994, 33, 869.

(2) Henry, L.; Schneider, C.; Mützel, B.; Simpson, P. V.; Nagel, C.; Fucke, K.; Schatzschneider, U. Chem. Commun. 2014, 50, 15692.

(3) Greenfield, H.; Sternberg, H. W.; Friedel, R. A.; Wotiz, J. H.; Markby, R.; Wender, I. F. Am. Chem. Soc. 1956, 78, 120.

(4) Seyferth, D.; Wehman A. T.7. Am. Chem. Soc. 1970, 92, 5520.

(5) Nicholas, K. M.; Pettit, R. Tetrahedron Lett. 1971, 12, 3475.

(6) Lockwood, R. F.; Nicholas, K. M. Tetrahedron Lett. 1977, $18,4163$.

(7) Khand, I. U.; Knox, G. R.; Pauson, P. L.; Watts, W. E. 7. Chem. Soc. D, Chem. Commun. 1971, 36.

(8) Jeong, N.; Hwang, S. H.; Lee, Y.; Chung, Y. K. 7. Am. Chem. Soc. 1994, 116,3159 .

(9) Low, P. J.; Rousseau, R.; Lam, P.; Udachin, K. A.; Enright, G. D.; Tse, J. S.; Wayner, D. D. M.; Carty, A. J. Organometallics 1999, 18 , 3885.

(10) Low, P. J.; Udachin, K. A.; Enright, G. D.; Carty, A. J. F. Organomet. Chem. 1999, 578, 103.

(11) Macazaga, M. J.; Marcos, M. L.; Moreno, C.; Benito-Lopez, F.; Gomez-González, J.; González-Velasco, J.; Medina, R. M. J. Organomet. Chem. 2006, 691, 138.
(12) Bruce, M. I.; Smith, M. E.; Zaitseva, N. N.; Skelton, B. W.; White, A. H. F. Organomet. Chem. 2003, 670, 170.

(13) Diederich, F.; Rubin, Y. Angew. Chem. Int. Ed. Engl. 1992, 31, 1101.

(14) Neenan, T. X.; Whitesides, G. M. F. Org. Chem. 1988, 53, 2489.

(15) Chalifoux, W. A.; Tykwinski, R. R. Nat. Chem. 2010, 2, 967.

(16) Diederich, F.; Kivala, M. Adv. Mater. 2010, 22, 803.

(17) Schrettl, S.; Stefaniu, C.; Schwieger, C.; Pasche, G.; Oveisi, E.; Fontana, Y.; i Morral, A. F.; Reguera, J.; Petraglia, R.; Corminboeuf, C.; Brezesinski, G.; Frauenrath, H. Nat. Chem. 2014, 6, 468.

(18) Jevic, M.; Nielsen, M. B. Asian 7. Org. Chem. 2015, 4, 286.

(19) Matsuoka, R.; Sakamoto, R.; Hoshiko, K.; Sasaki, S.; Masunaga, H.; Nagashio, K.; Nishihara, H. F. Am. Chem. Soc. 2017, 139, 3145.

(20) Rubin, Y.; Knobler, C. B.; Diederich, F. F. Am. Chem. Soc. 1990, 12, 4966.

(21) Haley, M. M.; Langsdorf, B. L. Chem. Commun. 1997, 1121.

(22) Shvo, Y.; Hazum, E. 7. Chem. Soc., Chem. Commun. 1974, 336.

(23) Cetini, G.; Gambino, O.; Rossetti, R.; Sappa, E. F. Organomet. Chem. 1967, 8,149

(24) Allison, N. T.; Fritch, J. R.; Vollhardt, K. P. C.; Walborsky, E. C. J. Am. Chem. Soc. 1983, 105, 1384.

(25) Meyer, A.; Gorgues, A.; Le Floc'h, Y.; Pineau, Y.; Guillevic, J.; Le Marouille, J. Y. Tetrahedron Lett. 1981, 22, 5181.

(26) Hanson, B. E.; Mancini, J. S. Organometallics 1983, 2, 126

(27) Lewis, J.; Lin, B.; Khan, M. S.; Al-Mandhary, M. R. A.; Raithby, P. R. F. Organomet. Chem. 1994, 484, 161.

(28) Eisler, S.; Tykwinski, R. R. 7. Am. Chem. Soc. 2000, 122, 10736.

(29) Luu, T.; Morisaki, Y.; Cunningham, N.; Tykwinski, R. R. F. Org. Chem. 2007, 72, 9622.

(30) Luu, T.; Elliott, E.; Slepkov, A. D.; Eisler, S.; McDonald, R.; Hegmann, F. A.; Tykwinski, R. R. Org. Lett. 2005, 7, 51.

(31) Diederich, F.; Rubin, Y.; Knobler, C. B.; Whetten, R. L.; Schriver, K. E.; Houk, K. N.; Li, Y. Science 1989, 245, 1088.

(32) Rubin, Y.; Kahr, M.; Knobler, C. B.; Diederich, F.; Wilkins, C. L. 7 . Am. Chem. Soc. 1991, 113, 495.

(33) Eisler, S.; Slepkov, A. D.; Elliott, E.; Luu, T.; McDonald, R. Hegmann, F. A.; Tykwinski, R. R. F. Am. Chem. Soc. 2005, 127, 2666.

(34) Tobe, Y.; Fujii, T.; Naemura, K. F. Org. Chem. 1994, 59, 1236.

(35) Tobe, Y.; Fujii, T.; Matsumoto, H.; Naemura, K.; Achiba, Y.; Wakabayashi, T.7. Am. Chem. Soc. 1996, $118,2758$.

(36) Tobe, Y.; Umeda, R.; Iwasa, N.; Sonoda, M. Chem. Eur. 7 2003, 9, 5549 .

(37) Movsisyan, L. D.; Franz, M.; Hampel, F.; Thompson, A. L.; Tykwinski, R. R.; Anderson, H. L. 7. Am. Chem. Soc. 2016, 138, 1366.

(38) Kohn, D. R.; Movsisyan, L. D.; Thompson, A. L.; Anderson, H. L. Org. Lett. 2017, 19, 348.

(39) Zhao, Y.; Slepkov, A. D.; Akoto, C. O.; McDonald, R.; Hegmann, F. A.; Tykwinski, R. R. Chem. Eur. 7. 2005, 11, 321.

(40) Platonov, A. Y.; Evdokimov, A. N.; Kurzin, A. V.; Maiyorova, H. D. 7. Chem. Eng. Data 2002, 47, 1175.

(41) Anderson, H. L. Inorg. Chem. 1994, 33, 972.

(42) Eglinton, G.; Galbraith, A. R. Chem. Ind. 1956, 737.

(43) Diederich, F.; Rubin, Y.; Chapman, O. L.; Goroff, N. S. Helv. Chim. Acta 1994, 77, 1441.

(44) Hay, A. S. F. Org. Chem. 1962, 27, 3320.

(45) Saito, S.; Takahashi, E.; Nakazono, K. Org. Lett. 2006, 8, 5133.

(46) Weisbach, N.; Baranová, Z.; Gauthier, S.; Reibenspies, J. H.; Gladysz, J. A. Chem. Commun. 2012, 48, 7562.

(47) Movsisyan, L. D.; Kondratuk, D. V.; Franz, M.; Thompson, A. L; Tykwinski, R. R.; Anderson, H. L. Org. Lett. 2012, 14, 3424.

(48) Marini, A.; Muñoz-Losa, A.; Biancardi, A.; Mennucci, B. 7. Phys. Chem. B 2010, 114, 17128.

(49) Reichardt, C. Chem. Rev. 1994, 94, 2319.

(50) Szafert, S.; Gladysz, J. A. Chem. Rev. 2006, 106, PR1.

(51) Chalifoux, W. A.; McDonald, R.; Ferguson, M. J.; Tykwinski, R. R. Angew. Chem. Int. Ed. 2009, 48, 7915.

(52) Yang, S.; Kertesz, M. F. Phys. Chem. A 2006, 110, 9771.

(53) Palatinus, L.; van der Lee, A. F. Appl. Crystallogr. 2008, 41, 975.

(54) Palatinus, L. Acta Cryst. B 2013, 69, 1.

(55) Palatinus, L.; Chapuis, G. J. Appl. Crystallogr. 2007, 40, 786.

(56) Betteridge, P. W.; Carruthers, J. R.; Cooper, R. I.; Prout, K.; Watkin, D. J. F. Appl. Crystallogr. 2003, 36, 1487.

(57) Cooper, R. I.; Thompson, A. L.; Watkin, D. J. J. Appl. Crystallogr. 2010, 43, 1100 . 